Review

\title{
Fungal Biofilms as a Valuable Target for the Discovery of Natural Products That Cope with the Resistance of Medically Important Fungi-Latest Findings
}

\author{
Estefanía Butassi $^{1,+}$, Laura Svetaz ${ }^{1,+}$, María Cecilia Carpinella ${ }^{2}$, Thomas Efferth ${ }^{3}$ and Susana Zacchino ${ }^{1, *}$ \\ 1 Pharmacognosy Area, School of Biochemical and Pharmaceutical Sciences, Universidad Nacional de Rosario, \\ Suipacha 531, Rosario 2000, Argentina; fefabutassi@hotmail.com (E.B.); laurasvetaz@hotmail.com (L.S.) \\ 2 Fine Chemical and Natural Products Laboratory, IRNASUS CONICET-UCC, Universidad Católica de \\ Córdoba, Córdoba 5016, Argentina; ceciliacarpinella@ucc.edu.ar \\ 3 Institute of Pharmaceutical and Biomedical Sciences, Johannes Gutenberg University, Staudinger Weg 5, \\ 55128 Mainz, Germany; efferth@uni-mainz.de \\ * Correspondence: szaabgil@gmail.com \\ + These authors contributed equally to this work.
}

check for

updates

Citation: Butassi, E.; Svetaz, L.; Carpinella, M.C.; Efferth, T.; Zacchino,

S. Fungal Biofilms as a Valuable Target for the Discovery of Natural Products That Cope with the Resistance of Medically Important Fungi-Latest Findings. Antibiotics 2021, 10, 1053. https://doi.org/ 10.3390/antibiotics10091053

Academic Editor: María Auxiliadora Dea-Ayuela

Received: 26 July 2021

Accepted: 26 August 2021

Published: 30 August 2021

Publisher's Note: MDPI stays neutral with regard to jurisdictional claims in published maps and institutional affiliations.

Copyright: (c) 2021 by the authors. Licensee MDPI, Basel, Switzerland. This article is an open access article distributed under the terms and conditions of the Creative Commons Attribution (CC BY) license (https:/ / creativecommons.org/licenses/by/ $4.0 /)$.

\begin{abstract}
The development of new antifungal agents that target biofilms is an urgent need. Natural products, mainly from the plant kingdom, represent an invaluable source of these entities. The present review provides an update (2017-May 2021) on the available information on essential oils, propolis, extracts from plants, algae, lichens and microorganisms, compounds from different natural sources and nanosystems containing natural products with the capacity to in vitro or in vivo modulate fungal biofilms. The search yielded 42 articles; seven involved essential oils, two Brazilian propolis, six plant extracts and one of each, extracts from lichens and algae/cyanobacteria. Twenty articles deal with the antibiofilm effect of pure natural compounds, with 10 of them including studies of the mechanism of action and five dealing with natural compounds included in nanosystems. Thirty-seven manuscripts evaluated Candida spp. biofilms and two tested Fusarium and Cryptococcus spp. Only one manuscript involved Aspergillus fumigatus. From the data presented here, it is clear that the search of natural products with activity against fungal biofilms has been a highly active area of research in recent years. However, it also reveals the necessity of deepening the studies by (i) evaluating the effect of natural products on biofilms formed by the newly emerged and worrisome health-care associated fungi, C. auris, as well as on other non-albicans Candida spp., Cryptococcus sp. and filamentous fungi; (ii) elucidating the mechanisms of action of the most active natural products; (iii) increasing the in vivo testing.
\end{abstract}

Keywords: fungal biofilm; antifungal resistance; natural products; Candida spp.; Fusarium spp.; Cryptococcus spp.; filamentous fungi; mechanisms of antibiofilm action

\section{Introduction}

In recent decades, fungi has emerged as a major cause of life-threatening invasive human infections, in particular among immunocompromised patients [1-3], particularly those with human immunodeficiency virus (HIV), cancer patients receiving chemotherapy, transplant recipients, extremely aged persons and subjects in intensive care units $[4,5]$. Fungal infections lead to mortalities estimated in 1.5 million per year, having a great impact on global human health [5]. The main purpose of this review is to provide an updated analysis of the natural products with a capacity of inhibiting fungal biofilms, published from 2017 to May 2021.

We collected papers on essential oils (EOs), propolis, extracts from plants, algae, lichens and microorganisms, metabolites obtained from these sources and nanosystems. 


\subsection{Most Common Etiological Agents Causing Fungal Infections}

The most common fungi identified in systemic infections are the yeasts of the Candida and Cryptococcus genera, as well as the filamentous fungi of the Aspergillus genus [6-8]. Candida spp. produce a $40 \%$ mortality rate [2,9], while cryptococcosis and aspergillosis produce a mortality rate between $20 \%$ to $90 \%$ [9]. Among Candida spp., C. albicans showed to be the fourth most common cause of nosocomial bloodstream infections [10], although a recent global shift in epidemiology towards non-albicans Candida spp., such as C. glabrata, C. parapsilopsis, C. tropicalis, C. krusei and lastly, C. auris, has been detected [11,12]. Apart from the mentioned fungi, other species such as Pneumocystis jirovecii, Histoplasma capsulatum and the mucormycetes of Mucor, Absidia and Rhizopus genera, are important fungal pathogens responsible for the majority of serious fungal diseases [13-15].

\subsection{Available Antifungal Agents}

Currently, five classes of antifungal agents, the polyenes, azoles, allylamines, echinocandins and pyrimidines are used for the treatment of fungal infections in human beings [16,17]. Some of them target ergosterol, an essential component of the fungal membrane, either by binding to it (i.e., polyenes such as amphotericin B) or by interfering with different steps of its biosynthesis (i.e., triazoles and allylamines) $[16,17]$. In particular, the interaction or sequestration of ergosterol by amphotericin B disturbs the membrane, which leads to an increased permeability and the leakage of the intracellular components resulting in the death of the pathogen [18-20]. Previous publications demonstrated that amphotericin B is also able to induce the generation of reactive oxygen species (ROS), as an additional mechanism to achieve the fungicidal activity [21]. On the other hand, the triazoles (i.e., fluconazole, voriconazole, itraconazole, isavuconazole and posaconazole) inhibit the enzyme lanosterol $14 \alpha$-demethylase responsible for the demethylation of $14 \alpha$-lanosterol [16] to form ergosterol in a process dependent on the cytochrome P450 system [22,23]. Allylamines, such as terbinafine, interfere with the activity of squalene epoxidase, the enzyme that catalyzes the stereospecific epoxidation of squalene to 2,3-(S)-oxidosqualene involved in ergosterol synthesis [24-26]. In addition to ergosterol, 1,3- $\beta$ glucan, present in fungal cell walls, is another target for antifungal drugs due to its role in fungal growth, integrity and division as well as its participation as a virulence factor $[27,28]$. The echinocandins (i.e., caspofungin, micafungin and anidulafungin) exhibit a noncompetitive inhibition of the $1,3-\beta$-D-glucan synthase, leading to a deficiency of this polymer [23,29]. The pyrimidine analogue flucytosine, selectively interferes with fungal DNA synthesis by inhibiting the thymidylate synthetase, a key enzyme acting as a crucial source of thymidine.

Although the different types of discovered antifungal drugs have enabled progress in the management of fungal infections, serious problems regarding side effects, limited options of antifungals and mainly the development of drug resistance [30-33], highlight the urgent need of exploring new therapeutic approaches that overpass the unmet clinical needs [34-36].

\subsection{Fungal Biofilms}

The most difficult-to-eradicate mycoses are not caused by planktonic cells, but by immobilized fungi (sessile cells) that form well-structured biofilms with the ability to adhere to different surfaces, organs or to medical devices such as catheters [37,38]. Biofilms (Figure 1) are the predominant growth lifestyle of many opportunistic fungal pathogens, e.g., albicans and non-albicans Candida spp., Cryptococcus neoformans, Cryptococcus gatti, Trichosporon asahii, Rhodotorula spp., Aspergillus fumigatus, Malassezia pachydermatis, Histoplasma capsulatum, Coccidioides immitis, Pneumocystis spp., Fusarium spp. and many others [39]. The National Institute of Health estimated that microbial biofilms were responsible for over $80 \%$ of all infections [40].

A biofilm is defined as a community of microorganisms encapsulated in a selfproduced exopolysaccharide matrix (EPM) attached to a biotic or abiotic surface [41,42], which plays a key role in its resistance [43]. The composition of the EPM produced by differ- 
ent fungi has been reviewed by Mitchell et al. [44]. Particularly, it contains carbohydrates, hexosamine, phosphorus, proteins, uronic acid and environmental DNA (eDNA) which were initially identified in C. albicans EPM [45]. This matrix is composed by 55\% protein, $25 \%$ carbohydrate, $15 \%$ lipid and 5\% nucleic acids [46]. The most abundant polysaccharides included $\alpha-1,2$ branched $\alpha-1,6$-mannans (87\%) associated with unbranched $\beta-1,6$-glucans $(13 \%)$ in an apparent mannan-glucan complex, while $\beta-1,3$ glucan comprised only a small portion of the total EPM carbohydrates [46]. The presence of $\beta-1,3$ glucan has been recently reported in C. glabrata biofilms [47] being a key carbohydrate component in fungal cell walls $[47,48]$.

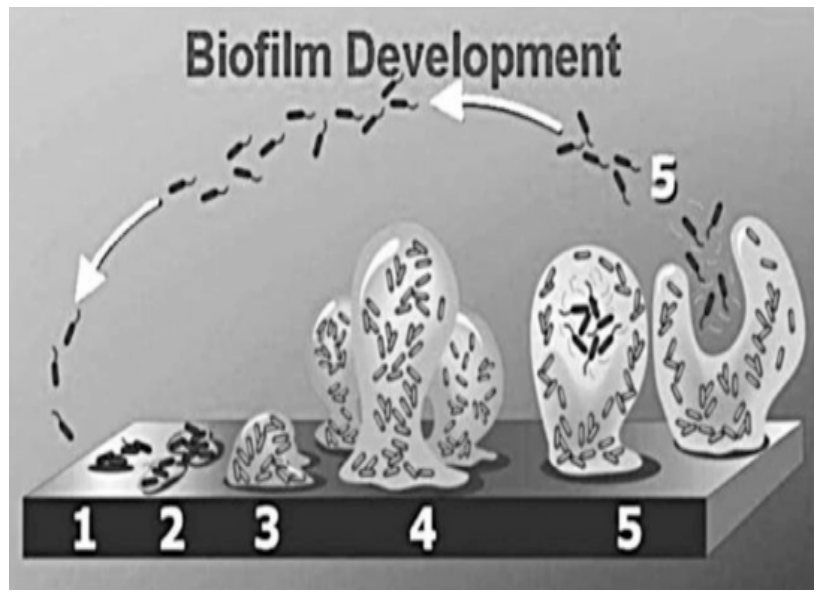

(a)

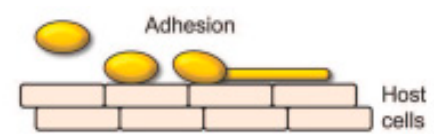

(b)

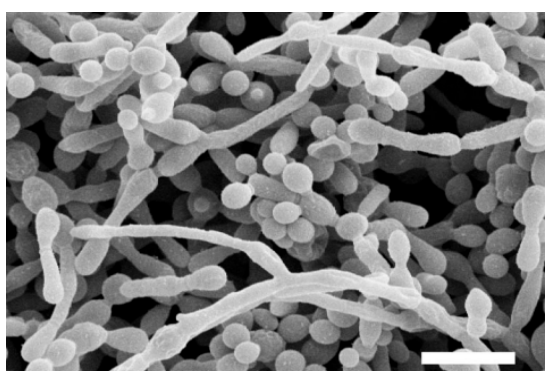

(c)

Figure 1. (a) The five-stage process involved in the development of biofilm: 1 . adherence of yeasts to a surface followed by yeast-to-hyphal transition; 2 . the exopolymeric matrix (EPM) is produced resulting in a firmly adhered "irreversible" attachment; 3. early biofilm architecture is developed; 4 . the biofilm reaches maturation in a three-dimensional structure and 5. single planktonic cells are dispersed from the mature biofilm. Reproduced from Stoodley et al., 2002 [49]. Image credit: D. Davies, with permission of Prof. David Davies. (b) A clearer scheme of stage 1. Yeasts adhere to host cell surfaces. Contact to host cells triggers the yeast-to-hyphal transition and directed growth via thigmotropism. Reproduced from part of Figure 1a from Mayer et al. [51], with permission. (c) A scan electron microscopy (SEM) image of a mature (48 h) Candida albicans biofilm (formed in stage 4 of Figure 1a). Bar $=10 \mu \mathrm{m}$. Yeasts, hyphae, and pseudohyphae can be observed. Most EPM was lost during the SEM procedures. Reproduced from Ramage et al. [50] with permission.

\subsection{Stages in the Development of Biofifilms}

The development of a biofilm involves five stages that were clearly explained and graphed by Stoodley et al. [49], Ramage et al. [50], Mayer et al. [51] and other authors [43,52-54]. In stage 1, planktonic cells adhere to a biotic or abiotic surface, followed by a yeast-to-hyphal transition (Figure 1a,b). In the second stage, EPM is produced, resulting in a firmly adhered irreversible attachment. In stage 3 an early biofilm architecture is developed, while in stage 4 the biofilm reaches maturation in a three-dimensional structure (Figure 1c). Finally, in stage 5, single planktonic cells are dispersed from the mature biofilm. This dispersion is an important step in the fungal biofilm development cycle, which can induce either bloodstream or invasive fungal infections [55] leading to an increased pathogenicity [56] and high risk of mortality [57,58]. This consortium of cells offers the optimum conditions for the fungi to obtain nutrients, dispose waste products and protect from the environment [58]. Once the biofilm is formed, the sessile cells communicate with each other through quorum sensing (QS) molecules that induce the fungal population to cooperate in diverse defense behaviors such as virulence and biofilm formation [59-61]. The sesquiterpene farnesol and the aromatic alcohol tyrosol are the two reported natural 
occurring QS molecules [62,63]. The first inhibits filamentation and biofilm formation in C. albicans [64] while tyrosol stimulates the germ tube formation and, thus, filamentation [63].

\subsection{Factors and Mechanisms Associated with Biofilm Resistance}

One of the major characteristics of biofilms is the enhanced resistance to antimicrobial agents [65-69]. It has been reported that they possess about 5- to 4000-times less susceptibility to antifungals than equivalent populations of planktonic cells [60,69-72], which is a decisive factor driving therapeutic failures [73].

Several factors appear to be responsible for the resistance of biofilms [74-76]: (i) EPM acts as a physical barrier, preventing the entry of antifungals to biofilms, by either slowing drug diffusion or through specific sequestration mechanisms [74], with EPM components playing key roles [75]. For instance, soluble 1,3- $\beta$ glucan, released from the fungal cell wall of C. albicans and A. fumigatus is able to sequester antifungal molecules, especially azole and polyene drugs, thus preventing their access to biofilm cells [68,76,77]; (ii) ergosterol levels are significantly lower at intermediate and mature phases of biofilms, compared to those in early phase biofilms and, therefore, those antifungals which target ergosterol have a poorer effect [78]. (iii) Although most sessile cells can show susceptibility to antifungal agents, a small sub-population of cells (persisters) stay alive [79], protected by the EPM and with a smaller oxidative imbalance compared to planktonic cells [80]. These persister cells can survive both the antifungal treatment and the immune system [81]. When the concentration of antifungal decreases, persister cells revive and repopulate the biofilm [81-83]. (iv) One of the major mechanisms of resistance to several classes of antifungals is the overexpression of efflux pumps [73]. These proteins imbibed in membranes are able to export the antimicrobial agents out of the cells, leading to a reduced intracellular concentration, which hinders the desired pharmacological effect.

The expression of different genes associated with resistance occurs during biofilm formation and maturation. The most prominent classes of transporters are those belonging to the ATP binding cassette (ABC) and major facilitator superfamily (MFS) [84]. In Candida spp., the ABC transporters Cdr1p and Cdr2p, and the MFS transporter Mdr1p, emerged as the main contributors in biofilm-associated resistance to a range of antifungal agents, mainly to the azoles [6,85]. The expression of the transporters Cdr1p, Cdr2p and Mdr1p showed a dependency with the developmental phases of biofilms, therefore leading to different degrees of susceptibility associated with the outward transport of drugs. The overexpression of $C D R 1, C D R 2$ and MDR1 genes occurred at the early stages of biofilm formation, being the prominent mechanism for the tolerance to fluconazole, while in mature biofilms other resistance mechanisms are also involved in the diminished susceptibility to this azole drug $[65,78,86]$.

In turn, the increase of drug resistance to antifungals, such as fluconazole and amphotericin B during biofilm maturation, seems to be associated with a significant decrease in the total ergosterol content, with changes in the expression of some ERG genes involved in its biosynthesis compared to planktonic cells [87]. Mutations or overexpression in the ERG11 gene, which encodes lanosterol $14 \alpha$-demethylase [88,89], as well as in other ERG genes such ERG1 (encodes squalene epoxidase), ERG3 (encodes D5,6-desaturase), ERG7 (encodes squalene cyclase), ERG9 (encodes squalene synthase) or ERG25 (encodes C-4 methyl sterol oxidase) play important roles in the resistance of fungi to different antifungal agents [72,90-92].

\subsection{Methodologies to Assess Antibiofilm Activity}

At present, in vitro and in vivo assays are used for quantifying biofilms [93]. Several methods for the in vitro assessing of the minimum inhibitory concentrations of biofilm sessile cells have been developed. The most commonly used assay is based on a static model using a microtiter plate [94], where the microbial biomass or metabolic activity are quantitated using dyes such as crystal violet (CV), 2,3-bis (2-methoxy-4-nitro-5sulfophenyl)-5-[(phenylamino) carbonyl]-2H-tetrazolium hydroxide (XTT), or fluorescein 
diacetate or resazurin [95]. Additionally, colony-forming units (CFU) counting has been extensively used [96]. Flow cytometry, using different fluorophores, can be used for determining CFU [7]. Another stain is calcofluor white (CW), which binds to 1,3 and 1,4 carbohydrate linkages and fluoresces under long-wave UV light [97]. Other biofilm devices or microscopy techniques such as light, confocal laser scanning microscopy (CLSM) and scanning electron microscopy (SEM), among others, have been extensively used $[96,98,99]$. To determine the inhibition of biofilm 'formation', compounds are incorporated during the biofilm growth phase. Instead, to assess biofilm 'eradication', biofilms are grown for $24 \mathrm{~h}$, after which the compounds are added and biofilms are additionally incubated $24-48 \mathrm{~h}$ in the presence of the compounds. The minimum biofilm inhibitory concentrations (MBIC, $\mathrm{MBIC}_{80}$ or $\mathrm{MBIC}_{50}$ ) are the minimum concentrations resulting in 100,80 or $50 \%$ inhibition of biofilm formation, respectively [100]. Similarly, the minimum biofilm eradication concentration $\mathrm{MBEC}, \mathrm{MBEC}_{80}$ or $\mathrm{MBEC}_{50}$ are the minimum concentrations resulting in $100 \%$, $80 \%$ or $50 \%$ eradication of mature biofilms, respectively [101].

The worm Caenorhabditis elegans is highly used for the in vivo antibiofilm effectiveness of compounds, since hyphal formation is able to kill C. elegans [102]. Results are expressed as percentages of living or dead worms after incubation for a given number of days [93]. Several other models such as the venous catheter model in rats, rabbit or mice [93]; urinary catheters, subcutaneous implants, denture stomatitis, and oral and vaginal mucosae in different animals, are used. All these models were thoroughly reviewed by Nett and Andes in 2015 [103].

\subsection{Natural Products as an Important Source of Antifungal Drugs}

Most antifungal agents in clinical use are natural or natural-derived compounds, mainly isolated from microbial strains [104]. For example, the polyenes nystatin and amphotericin B were isolated from Streptomyces spp. [105]; the spiro-diketone griseofulvin, was obtained from Penicillum griseofulvum [106]; the echinocandins caspofungin and anidulafungin are semisynthetic derivatives from the natural pneumocandin $B$, which was isolated from the fungus Glarea lozoyensis [107]. In turn, micafungin derived from the lipopeptide FR901379 was isolated from the fungus Coleophoma empetri [107], a plant pathogen associated with postharvest fruit rot in cranberries [108]. Under this scenario, it is clear that nature has provided a robust platform for finding novel scaffolds for the discovery of antifungal drugs.

Natural antifungal products were typically discovered using the traditional antifungal assays, which measure the inhibition of growth of yeasts and filamentous fungi in their planktonic state, thus free-floating in the culture medium [109]. Recent works have reported extracts either from plants [110-112], algae [113,114], endophytic fungi [115] or marine fungi [116], as well as secondary metabolites such as phenols [111,117], flavonoids [118], naphtoquinones [119] and terpenoids [120], which showed growth inhibitory properties of fungi in their planktonic state. Both recent and previous reviews reported several pure natural products that have shown antifungal activity assessed with this type of techniques. However, none of these compounds have become leads for the development of new antifungal drugs [121].

The aim of this present review is to provide an update (2017-May 2021) on the natural products (extracts and secondary metabolites) that possess the ability to in vitro or in vivo modulate fungal biofilms not only constituted by C. albicans and some non-albicans Candida yeasts, but also by fungi from other genera. When available, the mechanism of action of these natural products has been included. To this purpose, most data published in the literature from 2017 were collected with the objective of drawing conclusions that can be useful for future research. Previously, some reviews on this subject were published [122-126] by Nazzaro et al. [123] and Singla and Dubey [124], with very few references each regarding the effect against fungal biofilms after 2017. 


\section{Reported Antibiofilm Activities of EOs, Propolis and Extracts from Plants, Algae and Cyanobacteria}

Different studies involving EOs with antibiofilm activity are recorded in Table 1. Peixoto et al. [127] reported that Laurus nobilis L. (Lauraceae) EO at $2 \times$ minimum inhibitory concentration (MIC, $1000 \mu \mathrm{g} / \mathrm{mL}$ ) inhibited the initial adhesion of $C$. albicans, while at $2 \times$ and $4 \times$ MIC, it inhibited biofilm formation and also reduced the eradication of mature biofilms with no significant difference when compared to the positive control, nystatin. In another study, Manoharan et al. [128] screened 83 EOs against $C$. albicans biofilm formation. Six of them obtained from Croton eluteria (L.) W.Wright (Euphorbiaceae) (cascarilla bark), Helichrysum coriaceum (DC.) Harv. (Asteraceae) (helichrysum oil), Eucalyptus globulus Labill. (Myrtaceae), Cymbopogon citratus (DC.) Stapf (Poaceae) (lemongrass), Citrus aurantiifolia (Christm.) Swingle (Rutaceae) (lime oil) and Coriandrum satioum L. (Apiaceae) (coriander) were demonstrated to inhibit more than $90 \%$ of biofilm formation when tested at $0.01 \%$. Among them, cascarilla bark and helichrysum oil and their main components, $\alpha$-longipinene and linalool, significantly reduced the yeast-to-hyphal transition, adherence and biofilm formation and greatly inhibited invasive hyphal growth in the nematode C. elegans. Serra et al. [129] tested different commercial EOs against two C. albicans strains. The results showed that only Pelargonium graveolens L'Hér. (Geraniaceae) (geranium) and Melisa officinalis L. (Lamiaceae) (melissa) EOs, eradicated mature biofilms with $\mathrm{MBEC}_{80}$ of 22.3 and $17.9 \mu \mathrm{g} / \mathrm{mL}$, respectively for geranium and of $13.3 \mu \mathrm{g} / \mathrm{mL}$ on both strains, for melissa. 
Table 1. More relevant results of essential oils (EOs) showing a capacity for inhibiting fungal biofilms.

\begin{tabular}{|c|c|c|c|c|c|c|c|}
\hline Year & Essential Oil From & Fungal spp. Biofilm & In Vitro Type of Studies & & & & Reference \\
\hline & & & $\begin{array}{l}\text { Inhibition of Cell Adhesion } \\
\text { or Hyphal Formation }\end{array}$ & $\begin{array}{l}\text { Inhibition of Biofilm } \\
\text { Formation }\end{array}$ & $\begin{array}{l}\text { Eradication of Mature } \\
\text { Biofilms }\end{array}$ & $\begin{array}{l}\text { Mechanism of Action or In } \\
\text { Vivo Assays }\end{array}$ & \\
\hline 2017 & Laurus nobilis & $\begin{array}{l}\text { C. albicans ATCC 60193; CBS } \\
\text { 562; C. tropicalis ATCC 750; } \\
\text { CBS 94 and C. krusei ATCC } \\
\text { 3413; CBS 73 }\end{array}$ & $\begin{array}{l}\text { L. nobilis } \mathrm{EO} \text { at } 1000 \mu \mathrm{gg} / \mathrm{mL} \\
\text { inhibited the initial adhesion } \\
\text { of C. albicans biofilms }\end{array}$ & $\begin{array}{l}\text { At } 1000 \text { and } 2000 \mu \mathrm{g} / \mathrm{mL} \text {, the } \\
\text { EO showed significant } \\
\text { inhibition of biofilm } \\
\text { formation }\end{array}$ & $\begin{array}{l}\text { L. nobilis EO at } 1000 \text { and } 2000 \\
\mu \mathrm{g} / \mathrm{mL} \text { reduced the amount } \\
\text { of mature biofilms }\end{array}$ & & [127] \\
\hline 2017 & $83 \mathrm{EOs}$ & $\begin{array}{l}\text { C. albicans ATCC } 10231, \\
18804,24433 \text { and DAY1 } 85\end{array}$ & $\begin{array}{l}\text { Croton eluteria reduced the } \\
\text { Candida adherence } \\
\text { by } 75 \%\end{array}$ & $\begin{array}{l}\text { Six EOs, C. eluteria, } \\
\text { Helichrysum coriaceum, } \\
\text { Eucalyptus globulus, } \\
\text { Cymbopogon citratus } \\
\text { andCoriandrum sativum } \\
\text { inhibited } 90 \% \text { of biofilm } \\
\text { formation }\end{array}$ & & $\begin{array}{l}\text { In vivo assay: C. eluteria EO } \\
\text { diminished Caenorhabditis } \\
\text { elegans virulence }\end{array}$ & [128] \\
\hline 2018 & $12 \mathrm{EOs}$ & $\begin{array}{l}\text { C. albicans } 135, \mathrm{BM} 2 / 94 \text { and } \\
\text { NYCY } 1363\end{array}$ & & & $\begin{array}{l}\text { Out of the } 12 \text { EOs tested, only } \\
\text { Pelargonium graveolens and } \\
\text { Melissa officinalis eradicated } \\
\text { mature biofilms }\end{array}$ & & [129] \\
\hline 2018 & $\begin{array}{l}\text { Pogostemon heyneanus, } \\
\text { Cinnamomum tamala and } \\
\text { Cinnamomum camphora }\end{array}$ & $\begin{array}{l}\text { C. albicans ATCC } 90028 ; C \text {. } \\
\text { glabrata MTCC } 6507 \text { and C. } \\
\text { tropicalis MTCC } 310\end{array}$ & $\begin{array}{l}\text { The three EOs produced a } \\
\text { reduction in the hyphal } \\
\text { formation with P. heyneanus } \\
\text { EO showing the maximum } \\
\text { inhibition }\end{array}$ & & $\begin{array}{l}\text { P. heyneanus and C. tamala } \\
\text { disrupted mature biofilms }\end{array}$ & $\begin{array}{l}\text { Candida biofilms EPM was } \\
\text { reduced. A large reduction of } \\
\text { sugars was observed }\end{array}$ & [130] \\
\hline 2019 & $\begin{array}{l}\text { Foeniculm vulgare EO } \\
\text { (fennel oil) }\end{array}$ & 10 isolates of $C$. albicans & & & $\begin{array}{l}\text { The } \text { MBEC }_{50} \text { of fennel oil for } \\
7 / 10 \text { tested strains was 2-to } \\
\text { 6-fold the MIC }\end{array}$ & & [131] \\
\hline 2021 & $\begin{array}{l}\text { Cymbopogon citratus and } \\
\text { (lemongrass) } \\
\text { Cinnamomum verum EOs } \\
\text { (cinnamom) }\end{array}$ & $\begin{array}{l}\text { C. albicans ATCC } 10231 \\
\text { biofilms, coated on } \\
\text { polymethyl methacrylate } \\
\text { (PMMA) resin }\end{array}$ & & $\begin{array}{l}\text { C. verum } \mathrm{EO} \text { at } 8 \times \mathrm{MIC} \text { and } \\
\text { C. citratus } \mathrm{EO} \text { at } 16 \times \mathrm{MIC}, \\
\text { precoated on PMMA, } \\
\text { inhibited C. albicans biofilm } \\
\text { formation by } 73 \% \text { and } 68 \% \text {, } \\
\text { respectively }\end{array}$ & $\begin{array}{l}\text { At } 8 \times \text { MIC, both EOs } \\
\text { eradicated totally the } \\
\text { pre-established fungal } \\
\text { biofilms in } 1 \mathrm{~h}\end{array}$ & & [133] \\
\hline
\end{tabular}

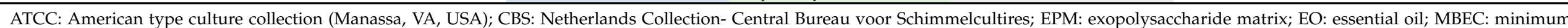

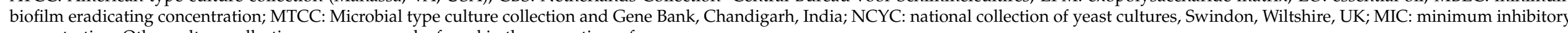
concentration. Other culture collection acronyms can be found in the respective reference. 
As reported by Banu et al. [130], EOs from Cinnamomum tamala (Buch.-Ham.) T. Nees and Eberm. (Lauraceae) (Indian cassia), Pogostemon heyneanus Benth (Lamiaceae) (Indian patchouli) and Cinnamomum camphora (L.) J.Presl (Lauraceae) (camphor) inhibited about $54 \%-65 \%$ of biofilms formed by C. albicans, C. glabrata and C. tropicalis. In addition, the three EOs reduced the Candida spp. preformed biofilms, with an inhibition range of $55 \%-67 \%$ at their MBICs $(0.5 \%-5 \% v / v)$; with $C$. tamala being the most active plant sp., P. heyneanus EO showed the maximum inhibition of yeast-to-hyphal transition. On the other hand, the EOs from P. heyneanus and C. tamala disrupted Candida spp. mature biofilms and reduced the thick aggregation of the yeast cells. This result was confirmed by the observation of a decrease of sugars present in the EPM layer.

The capacity of Foeniculum vulgare Mill. (Apiaceae) EO (fennel oil) to eradicate 10 strains of $C$. albicans biofilms was studied by Bassyouni et al. [131]. The $\mathrm{MBEC}_{50}$ of fennel oil for eradicating the 18-h-old biofilm was 2- to 16-fold of MIC, in 7/10 tested strains. Sahal et al. [132] investigated the antifungal and biofilm inhibitory effects of EOs by using $C$. tropicalis biofilms coated on different biomaterials. Treatments with $2 \%-8 \%$ of $C$. citratus EO coated on silicone rubber resulted in a $45 \%-76 \%$ reduction in biofilm formation of all the strains. Likewise, Cuminum cyminum L. (Apiaceae), Citrus limon (L.) Osbeck (Rutaceae) and Cinnamomum verum J.Presl (Lauraceae) EOs, were also effective in inhibiting the $C$. tropicalis biofilms in polystyrene plates at sub-MIC values. Therefore, the mentioned extracts, in particular $C$. citratus EO, could be used as an antibiofilm agent on silicone rubber prostheses and medical devices. C. tropicalis biofilms pose a serious risk for skin infections and may cause a shorter lifespan of the prosthesis. In an additional study, Choonharuangdej et al. [133] tested the efficacy of C. verum and C. citratus EOs for eradicating C. albicans biofilms established on heat-polymerized polymethyl methacrylate (PMMA) material and determined whether they were able to retard the formation of fungal biofilms and/or eradicate them. Results showed that cinnamom oil at $0.8 \mu \mathrm{L} / \mathrm{mL}(8 \times$ MIC) and lemongrass oil at $6.4 \mu \mathrm{L} / \mathrm{mL}(16 \times \mathrm{MIC})$, both coated on PMMA, inhibited the formation of C. albicans biofilms by $70.0 \%$ after $24 \mathrm{~h}$ of treatment. In contrast, at $8 \times$ MIC $(0.8$ and $3.2 \mu \mathrm{L} / \mathrm{mL}$, respectively), both EOs eradicated $99 \%$ of the pre-established C. albicans biofilm in $1 \mathrm{~h}$.

Table 2 shows the relevant studies on antifungal propolis with antibiofilm activity. Galletti et al. [134] evaluated the activity of green propolis collected in Paraná (Brazil) against Fusarium spp. biofilms that frequently cause disseminated infections in immunocompromised patients, with a high rate of mortality [135]. In the mentioned work, the authors used clinical isolates of F. oxysporum, F. solani and F. subglutinans and a standardized F. solani strain. The used propolis proved to be efficient to reduce both the total biomass (assessed with CV dye) and the number of viable cells (quantified with XTT) for all evaluated isolates. In addition, the CW fluorescence assay showed that biofilm structure was lost, leaving only isolated damaged cells. In a recent paper, Martorano Fernandes et al. [136] evaluated the inhibitory effects of Brazilian red propolis on C. albicans and a co-culture of C. albicans-C. glabrata biofilms. Metabolic activity determined by 3-(4,5-dimethylthiazol2-yl)-2,5-diphenyltetrazolium bromide (MTT) assay, and cell viability assessed with CFU counts and surface roughness (optical profilometry) were evaluated. Results showed that red propolis had high inhibitory mono sp-biofilm effects but low activity against co-cultured two spp. biofilm formation, compared to chlorhexidine. The surface roughness (Sa parameter) within the mono-sp. and the co-culture biofilms statistically differed among groups. Table 3 shows the different studies on extracts from plants, lichens, algae and cyanobacteria with antibiofilm activity. 
Table 2. More relevant results of propolis extracts showing a capacity for inhibiting fungal biofilms.

\begin{tabular}{|c|c|c|c|c|c|c|}
\hline Year & Extracts & Fungal Biofilms spp. & In Vitro Type of Studies & & & Reference \\
\hline & & & $\begin{array}{l}\text { Inhibition of Cell } \\
\text { Adhesion or Hyphal } \\
\text { Formation }\end{array}$ & Biofilm Formation & Eradication of Mature Biofilms & \\
\hline 2017 & $\begin{array}{l}\text { Propolis from Paraná state (Brazil) } \\
\text { diluted in EtOH (PE) quantified } \\
\text { in its total phenol content }\end{array}$ & $\begin{array}{l}\text { Fusarium spp. isolated from } \\
\text { onichomycoses and deposited in } \\
\text { UEM; F. oxysporum FO42; F. solani } \\
\text { FS04 and ATCC } 36031 \text { and F. } \\
\text { subglutinans (FSub39) }\end{array}$ & & & $\begin{array}{l}\text { The total mass of biofilms and the } \\
\text { number of viable cells were } \\
\text { significantly reduced by PE }\end{array}$ & [134] \\
\hline 2020 & $\begin{array}{l}\text { EtOH- } \mathrm{H}_{2} \mathrm{O} \text { extract of red propolis } \\
\text { (RPE) } \\
\text { from Paraiba state, Brazil }\end{array}$ & $\begin{array}{l}\text { C. albicans ATCC } 90028 \text { mono sp. } \\
\text { biofilm and C. albicans-C. glabrata } \\
\text { ATCC } 2001 \text { co-cultures biofilms }\end{array}$ & & $\begin{array}{l}\text { RPE at } 3 \% \text { showed a high and low } \\
\text { inhibitory capacity of inhibiting } \\
\text { the formation of mono sp.- and } \\
\text { co-cultured two spp. -biofilms, } \\
\text { respectively }\end{array}$ & & [136] \\
\hline
\end{tabular}

ATCC: American type culture collection (Manassas, VA, USA); EtOH: ethanol; UEM: mycological collection of the laboratory of medical mycology of the Universidade Estadual de Maringá, Brazil.

Table 3. More relevant results of extracts from plants, algae and cyanobacteria showing a capacity for inhibiting fungal biofilms.

\begin{tabular}{|c|c|c|c|c|c|c|}
\hline Year & Extracts & Fungal Biofilms spp. & In Vitro Type of Studies & & & Reference \\
\hline & Source and Solvent & & $\begin{array}{l}\text { Inhibition of Cell Adhesion or } \\
\text { Hyphal Formation }\end{array}$ & Biofilm Formation & Eradication of Mature Biofilms & \\
\hline \multicolumn{7}{|c|}{ PLANT EXTRACTS } \\
\hline 2017 & $\begin{array}{l}\text { Eugenia leitonii, } \\
\text { E. brasiliensis, } \\
\text { E. myrcianthes, } \\
\text { E. involucrata leaf, pulp, seed } \\
\text { and bark EtOH- } \mathrm{H}_{2} \mathrm{O} \text { extracts }\end{array}$ & C. albicans ATCC 90028 & & & $\begin{array}{l}\text { Treatment with E. leitonii seed } \\
\text { and E. brasiliensis seed and leaf } \\
\text { extracts at } 10 \times \text { MIC, reduced } \\
\text { C. albicans biofilm viability }\end{array}$ & [137] \\
\hline 2017 & $\begin{array}{l}\text { Malva sylvestris root } \mathrm{EtOH} \\
\text { extract }\end{array}$ & C. albicans ATCC 10231 & $\begin{array}{l}\text { M. sylvestris extract at } 0.19 \\
\mathrm{mg} / \mathrm{mL}(1 / 4 \mathrm{MIC}), \\
\text { down-regulated the expression } \\
\text { of the hypha-specific gene } \\
\text { HWP1 }\end{array}$ & $\begin{array}{l}\text { M. sylvestris EtOH extract at } \\
0.78 \text { and } 1.56 \mathrm{mg} / \mathrm{mL} \text { (MIC and } \\
2 \times \text { MIC) reduced biofilm } \\
\text { formation }\end{array}$ & & [138] \\
\hline 2019 & $\begin{array}{l}\text { Anadenantera colubrina bark } \\
\text { EtOH- } \mathrm{H}_{2} \mathrm{O} \text { extract }\end{array}$ & $\begin{array}{l}\text { C. albicans ATCC MYA2876, } \\
\text { ATCC } 90028 \text { and a clinical } \\
\text { isolate; C. parapsilopsis ATCC } \\
22019 \text { and C. krusei ATCC } 6258\end{array}$ & & & $\begin{array}{l}\text { Candida biofilms at } 500 \times \mathrm{MIC} \\
\text { underwent a decrease in the } \\
\text { number of CFU } / \mathrm{mL} \text {. Biofilm } \\
\text { structural alterations and } \\
\text { cellular destruction were } \\
\text { observed, being C. parapsilosis } \\
\text { and C. krusei the most affected } \\
\text { biofilms. }\end{array}$ & [139] \\
\hline 2020 & $\begin{array}{l}\text { Clematis flammula fresh leaves } \\
\text { (CFL) and Fraxinus angustifolia } \\
\text { fresh leaves (FAL) and bark } \\
\text { (FAB) EtOH extracts }\end{array}$ & C. albicans ATCC 10231 & $\begin{array}{l}\text { CFL, FAL and FAB produced a } \\
\text { very low germ tube formation } \\
\text { of } 7.57,2.29 \text { and } 1.17 \% \text {, } \\
\text { respectively in comparison to a } \\
\text { growth of } 50.89 \% \text { for the } \\
\text { control group }\end{array}$ & $\begin{array}{l}\text { The extracts inhibited biofilm } \\
\text { formation with } \mathrm{MBIC}_{50}=250 \\
\mu \mathrm{g} / \mathrm{mL} \text { for FAL and } 500 \\
\mu \mathrm{g} / \mathrm{mL} \text { for } \mathrm{FAB}, \text { while } \mathrm{CFL} \\
\text { showed a } \mathrm{MBIC}_{50}>1000 \\
\mu \mathrm{g} / \mathrm{mL}\end{array}$ & & [140] \\
\hline
\end{tabular}


Table 3. Cont

\begin{tabular}{|c|c|c|c|c|c|c|}
\hline Year & Extracts & Fungal Biofilms spp. & \multicolumn{3}{|l|}{ In Vitro Type of Studies } & \multirow{2}{*}{ Reference } \\
\hline & Source and Solvent & & $\begin{array}{l}\text { Inhibition of Cell Adhesion or } \\
\text { Hyphal Formation }\end{array}$ & Biofilm Formation & Eradication of Mature Biofilms & \\
\hline 2020 & $\begin{array}{l}\text { Hibiscus sabdariffa flower (Hs) } \\
\text { DMSO extract }\end{array}$ & $\begin{array}{l}\text { C. albicans isolated from } \\
\text { vulvo-vaginal candidiasis }\end{array}$ & $\begin{array}{l}\text { Hs extract inhibits the } \\
\text { yeast-to-hyphal transition and } \\
\text { biofilm adherence }(50 \% \text { at } 1.5 \\
\mathrm{mg} / \mathrm{mL} \text { and } 80 \% \text { at } 6.25 \\
\mathrm{mg} / \mathrm{mL})\end{array}$ & $\begin{array}{l}\text { Fungal cells incubated with Hs } \\
\text { extract at } 2.5 \mathrm{mg} / \mathrm{mL}\left(\frac{1}{2} \mathrm{MIC}\right) \text {, } \\
\text { inhibited the biofilm } \\
\text { maturation and, thus, the } \\
\text { biofilm formation }\end{array}$ & $\begin{array}{l}\text { Hs extract eradicated C. albicans } \\
\text { biofilms at } 3.12 \mathrm{mg} / \mathrm{mL} \text {. In vivo } \\
\text { assay with Caenorhabtidis } \\
\text { elegans showed that Hs } \\
\text { decreased the CFU of } \mathrm{C} \text {. } \\
\text { albicans } \mathrm{i}\end{array}$ & [141] \\
\hline 2020 & $\begin{array}{l}\text { Orthoshipon aristatus purple } \\
\text { leaf } n \text {-hexane extract }\end{array}$ & C. albicans ATCC 10231 & $\begin{array}{l}\text { O. aristatus extract at } 2 \mathrm{mg} / \mathrm{mL} \\
\text { reduced the adhesion of } C \text {. } \\
\text { albicans cells }\end{array}$ & $\begin{array}{l}\text { Mild inhibition of C. albicans } \\
\text { growth at the biofilm } \\
\text { development stage at } 2 \mathrm{mg} / \mathrm{mL}\end{array}$ & & [142] \\
\hline \multicolumn{7}{|c|}{ LICHENS } \\
\hline \multicolumn{7}{|c|}{ MICROALGAE AND CYANOBACTERIA } \\
\hline 2019 & $\begin{array}{l}675 \text { hexane, ethyl acetate and } \\
\text { methanol extracts obtained } \\
\text { from } 225 \text { microalgae and } \\
\text { cyanobacteria }\end{array}$ & $\begin{array}{l}\text { C. albicans and C. parapsilopsis } \\
\text { (voucher } \mathrm{N}^{\circ} \text { s not stated) }\end{array}$ & & $\begin{array}{l}\text { C. albicans and C. parapsilopsis } \\
\text { biofilm formation was inhibited } \\
\text { by } 308 \text { extracts. C. albicans } \\
\text { biofilms were particularly } \\
\text { sensitive to extracts from } \\
\text { Cryptophyta. Euglenophyta, } \\
\text { and Glaucophyta (three } \\
\text { completely unrelated lineages), } \\
\text { with MBIC }{ }_{50}=8 \mu \mathrm{\mu g} / \mathrm{mL} \text {. } \\
\text { Instead, Rhodohyyta spp. }_{\text {showed activity against } C \text {. }} \\
\text { parapsilopsis with MBIC }{ }_{50}=64 \\
\mu \mathrm{g} / \mathrm{mL}\end{array}$ & & [144] \\
\hline
\end{tabular}

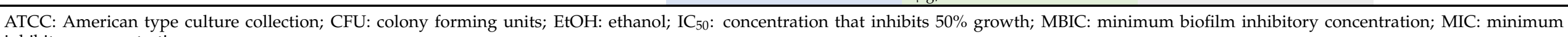
inhibitory concentration. 
Hydroethanol extracts of leaves, pulps, seeds and barks of several Eugenia spp. (Myrtaceae) such as E. leitonii Legrand, E. brasiliensis Lam., E. myrcianthes Nied. and E. involucrata DC. were tested for their capacity to eradicate mature C. albicans biofilms [137]. Among them, extracts from E. leitonii seeds and E. brasiliensis seeds and leaves reduced C. albicans biofilm viability by $54 \%, 54 \%$ and $55 \%$ at $156.2,156.2$ and $312.5 \mu \mathrm{g} / \mathrm{mL}(10 \times \mathrm{MIC})$, respectively, with better activity than that of nystatin which showed a $42 \%$ reduction. At these concentrations, all extracts caused damage to biofilm architecture and integrity, which could be observed by SEM. Alizadeh et al. [138] determined by CV assay that the ethanol extract of Malva sylvestris L. (Malvaceae) root at 0.78 and $1.56 \mathrm{mg} / \mathrm{mL}$ (MIC and $2 \times$ MIC, respectively) reduced C. albicans biofilm growth. By light microscopy, the authors observed that the extract was able to decrease biofilm thickness and cellular density. Silva et al. [139] determined that the hydroethanol extract of Anadenanthera colubrina Vell. Brenan (Fabaceae) barks, from the Caatinga biome (Brazil), showed the capacity to eradicate mature biofilms formed by four C. albicans strains, and one of each C. parapsilopsis and C. krusei, causing, in the last two, a 100\% decrease of biofilms at 500 $\times$ MIC. The Algerian Clematis flammula L. (Ranunculaceae) ethanol leaves (CFL) and Fraxinus angustifolia Vahl. (Oleaceae) leaves (FAL) and bark (FAB) extracts at $500 \mu \mathrm{g} / \mathrm{mL}$ showed $36.8 \%, 62.4 \%$ and $54.8 \%$ inhibition of $C$. albicans biofilm formation, respectively, which was probably related to the disruption of the cell surface hydrophobicity (CSH) and to the inhibition of germ tube and hyphae formation [140]. After four h incubation, 66.32\% of hyphal form was seen in the control group, while $3.96 \%, 2.11 \%$ and $1.65 \%$ of hyphae were formed in the presence of CFL, FAL and FAB, respectively [140]. As reported by Dwivedi et al. [141], the Hibiscus sabdariffa L. (Malvaceae) flower DMSO extract inhibited the yeast-to-hypha transition with hyphae showing morphological changes, and also adherence of $C$. albicans cells $(80 \%$ at $6.25 \mathrm{mg} / \mathrm{mL})$. It also inhibited biofilm formation as well as disrupted the pre-formed C. albicans biofilm by $50 \%$ when tested at $3.12 \mathrm{mg} / \mathrm{mL}$. The hexane extract of purple leaves from Orthosiphon aristatus (Blume) Miq. (Lamiaceae) was tested on different biofilm stages. [142]. Treatments of C. albicans with the extract at $2 \mathrm{mg} / \mathrm{mL}$, showed a $69.2 \%$ decrease in cell viability (assessed with MTT) at the adhesion stage, while fluconazole at $6 \mu \mathrm{g} / \mathrm{mL}$ caused a $54.7 \%$ reduction. It is important to highlight that a $50 \%$ reduction in cell density compared to the negative control was observed in the presence of $1.3 \mathrm{mg} / \mathrm{mL}$ of the extract, as determined by the CV assay. At the development stage, a $57.1 \%$ and $57.3 \%$ inhibition on C. albicans growth, in the presence of the extract and fluconazole respectively, was observed. A low inhibition of approximately $20 \%$ was observed on mature biofilms after treatment with both the extract and fluconazole [142]. The ability to inhibit the formation (named in this paper 'anti-maturation') or to eradicate preformed 24 h-old C. albicans biofilms (named 'antibiofilm') were evaluated for 38 lichen acetone extracts, by XTT assay [143]. Among them, eleven extracts showed antibiofilm activity, with seven displaying both anti-maturation and antibiofilm properties. Of them, extracts from Evernia prunastri (L.) Ach (Parmeliaceae) and Ramalina fastigiata (Pers.) Ach. (Ramalinaceae) were the most promising ones, with half inhibitory concentration $\left(\mathrm{IC}_{50}\right)$ values $<4 \mu \mathrm{g} / \mathrm{mL}$ for anti-maturation. E. prunastri, Cladonia uncialis (L.) Weber ex F.H.Wigg (Cladoniaceae), R. fastigiata and Xanthoparmelia conspersa (Ehrh. ex Ach.) (Parmeliaceae) extracts showed $\mathrm{IC}_{50}$ values $<10 \mu \mathrm{g} / \mathrm{mL}$ for antibiofilm eradication. Cepas et al. [144] tested 675 hexane, ethyl acetate and methanol extracts of 225 microalgae and cyanobacteria against C. albicans and C. parapsilopsis biofilms, which were inhibited by 308 extracts. Among the 11 phylum, the lowest activity was reported for Euglenophyta, with $\mathrm{MBIC}_{50}$ and $\mathrm{MBIC}_{90}$ of 8 and $16 \mu \mathrm{g} / \mathrm{mL}$, respectively; Cryptophyta showed $\mathrm{MBIC}_{50}$ and $\mathrm{MBIC}_{90}$ values of 8 and $128 \mu \mathrm{g} / \mathrm{mL}$ while Glaucophyta presented $\mathrm{MBIC}_{50}$ and $\mathrm{MBIC}_{90}$ values of 8 and $256 \mu \mathrm{g} / \mathrm{mL}$, respectively, against C. albicans. Instead, Rhodophyta spp. showed $\mathrm{MBIC}_{50}$ and $\mathrm{MBIC}_{90}$ values of 64 and $512 \mu \mathrm{g} / \mathrm{mL}$, respectively, against C. parapsilopsis. 


\section{Reported Antibiofilm Activities of Pure Natural Compounds}

Pure natural compounds with antibiofilm activity are summarized in Table 4 and detailed below. Liu et al. [145] demonstrated that the formyl-phloroglucinol meroditerpenoid, eucarobustol E (EE), isolated from Eucalyptus robusta Sm. (Myrtaceae), suppressed 73\% of C. albicans biofilm formation at $32 \mu \mathrm{g} / \mathrm{mL}$, destroyed nearly all mature biofilms (92\%) at $128 \mu \mathrm{g} / \mathrm{mL}$, blocked the yeast-to-hyphal transition and reduced the CSH at $16 \mu \mathrm{g} / \mathrm{mL}$. EE downregulated the expression of genes involved in hyphal growth (EFG1, CPH1, TEC1, EED1, UME6, and HGC1), cell surface proteins (ALS3, HWP1, and SAP5) and in ergosterol biosynthesis (ERG6, ERG13, ERG252, ERG11, ERG10, and ERG7). This activity resulted in the reduction of ergosterol, which alters cell membrane functions, leading to cell death. In turn, EE upregulated the farnesol-encoding gene DPP3, which negatively regulated biofilm formation. According to the authors, EE differs from clinical antifungal agents in their antibiofilm mechanisms and so it is certainly worth considering for further development as an antifungal drug. Shi et al. [146] reported that berberine (BBR) inhibited biofilm formation of 13 strains of $C$. tropicalis and one strain of each C. albicans, C. parapsilosis and C. glabrata with MBICs ranging from 64 to $256 \mu \mathrm{g} / \mathrm{mL}$. The mRNA expression of ERG11 and of the efflux proteins CDR1 and MDR1 were 1.43-2.10-fold upregulated by BBR at $16 \mu \mathrm{g} / \mathrm{mL}$. Behbehani et al. [147] found that the lignan magnolol (2-(2-hydroxy-5-prop2-enylphenyl)-4-prop-2-enylphenol), isolated from Magnolia officinalis Rehder and E.H. Wilson (Magnoliaceae), showed strong antibiofilm formation activity against C. albicans, C. dubliniensis and C. glabrata, with $69.5 \%, 46.7 \%$ and $35.6 \%$ at $32 \mu \mathrm{g} / \mathrm{mL}$, respectively, as determined by MTT assay. Six EO's components such as thymol, carvacrol, cinnamaldehyde, citral, menthol and eugenol were tested by Kumari et al. [148]. These compounds proved to be effective on biofilm formation and on preformed C. neoformans and C. laurentii biofilms in the following order: thymol $>$ carvacrol $>$ citral $>$ eugenol $=$ cinnamaldehyde $>$ menthol with $\mathrm{MBIC}_{80}$ ranging from 32 to $128 \mu \mathrm{g} / \mathrm{mL}$ and $\mathrm{MBEC}_{80}$ ranging from 64 to $256 \mu \mathrm{g} / \mathrm{mL}$, determined by XTT assay. SEM and CLSM showed the absence of EPM, reduction in cellular density and alteration of the surface morphology of biofilm cells. Cryptococcosis is a systemic infection [149] very difficult to treat due to the ability of these fungi to form biofilms resistant to standard antifungal treatments. Kumari et al. [150] deepened the study of the $C$. neofomans antibiofilm activity of thymol $(16 \mu \mathrm{g} / \mathrm{mL})$, carvacrol (32 $\mu \mathrm{g} / \mathrm{mL}$ ) and citral $(64 \mu \mathrm{g} / \mathrm{mL})$ using field emission scanning electron microscopy (FE-SEM), atomic force microscopy (ATM) and Fourier transform infrared spectroscopy. The three terpenes appear to act through the interaction with ergosterol or the inhibition of its biosynthesis, and the disruption of the biofilm cell surface, with pore formation and efflux of the $\mathrm{K}+$ /intracellular content. Morphological changes and qualitative/quantitative alterations in the EPM and in cellular components of $C$. neoformans biofilm cells were also observed. The terpenes-treated cells showed $35 \%-45 \%$ reduction in total carbohydrates, with variation in the type of glycosyl residues. Li et al., showed that the eudesmane sesquiterpene ent-isoalantolactone (ent-iLL) showed inhibition of the yeast-to-hyphal conversion of a mutant of C. albicans in assays performed in liquid and solid media at $8 \mu \mathrm{g} / \mathrm{mL}$ and $4 \mu \mathrm{g} / \mathrm{mL}$, respectively [151]. In addition, ent-iLL at $16 \mu \mathrm{g} / \mathrm{mL}$ reduced the presence of ergosterol in the membrane, through inhibiting the activity of Erg11 and Erg6 [151]. The polyphenol curcumin (Cur) was evaluated for their antibiofilm properties against C. albicans by Alalwan et al. [152]. The $\mathrm{MBIC}_{80}$, was $200 \mu \mathrm{g} / \mathrm{mL}$, as determined by XTT assay. Furthermore, Cur at $50 \mathrm{\mu g} / \mathrm{mL}$ was able to decrease C. albicans adhesion to a PMMA denture base material, an effect that could be enhanced by pre-treatment of the yeasts with the polyphenol. Regarding its molecular effects, Cur down-regulated the adhesin ALS3, with minimal effect on its related ALS1. On the contrary, the clustered aggregative and flocculation genes AAF1, EAP1, and ALS5 transcripts were up-regulated. Three gingerols (6-, 8- and 10-gingerols) and three shogaols (6-, 8-, and 10-shogaols) isolated from Zingiber officinale Roscoe (Zingiberaceae) showed antibiofilm and anti-virulence activities against a fluconazole-resistant $C$. albicans strain. Results showed that only 6-shogaol at $10 \mu \mathrm{g} / \mathrm{mL}$ and 6- and 8-gingerols at $50 \mu \mathrm{g} / \mathrm{mL}$, significantly reduced the C. albicans biofilm formation, suggesting that the 
increase in the length of the side chain decreased the activity. CLSM showed that biofilms treated with 6-gingerol and 6-shogaol were reduced in density and in thickness. In addition, both compounds inhibited hyphal growth in embedded colonies and free-living planktonic cells, and prevented cell aggregation, which was confirmed by SEM. Both entities significantly altered the expressions of some hypha-specific (HWP1 and ECE1), biofilmrelated (HWP1 and RTA3) and multidrug transporter (CDR1 and CDR2) related genes [153]. Yan et al. [154] reported that the 1,4-naphtoquinone derivative shikonin (SK), at $32 \mu \mathrm{g} / \mathrm{mL}$, inhibited almost totally C. albicans biofilm formation and eradicated the preformed mature biofilms, as evidenced with XTT assay and confirmed by CLSM. SK inhibited hyphae formation, showing a complete inhibition at $0.5 \mu \mathrm{g} / \mathrm{mL}$ in Lee's medium and reduced CSH by $70.3 \%$ at $2 \mu \mathrm{g} / \mathrm{mL}$. Several hypha and adhesion specific genes such as of ECE1, HWP1, EFG1, CPH1, RAS1, ALS1, ALS3 and CSH1 were downregulated while TUP1, NRG1 and BCR1 were upregulated by SK. In addition, SK induced the production of farnesol at 8 $\mu \mathrm{g} / \mathrm{mL}$, which enhanced its antibiofilm activity. Saibabu et al. [155] showed that different C. albicans strains treated with $62.5 \mu \mathrm{g} / \mathrm{mL}$ of vanillin showed few or no adherence to buccal epithelial cells. By MTT assay, it was observed the adherence of Candida cells to polystyrene surface was reduced by $52 \%$, the biofilm formation was decreased by $49 \%$, and the mature biofilm eradication decreased by $52 \%$. At $125 \mu \mathrm{g} / \mathrm{mL}$, vanillin protected C. elegans against C. albicans infection and enhanced its survival [155]. Kischkel et al. [156] evaluated farnesol on preformed F. solani complex biofilms particularly formed by Fusarium keratoplasticum, which is the most prevalent fungi related to biofilm formation in hospital water systems and in internal pipelines. Farnesol showed activity against F. keratoplasticum preformed biofilms, and was effective also during its formation at different times (at adhesion and at 24,48 and $72 \mathrm{~h}$ ) with a complete inhibition at $700 \mu \mathrm{M}$, as assessed by counting the CFU number and by $\mathrm{CV}$ and XTT assays.

A recent report from Wang et al. [157] described the isolation of 14 new terpenoids from the liverwort Heteroscyphus coalitus (Hook.) Schiffner (Geocalycaceae), including eight ent-clerodane diterpenoids, four labdane diterpenoids, heteroscyphsic acids A-I, heteroscyphins A-E, a harziane type diterpenoid and one guaiane sesquiterpene together with a known ent-junceic acid. At 4-32 $\mu \mathrm{g} / \mathrm{mL}$ most of these compounds inhibit hyphal and biofilm formation of an efflux pump deficient strain of $C$. albicans, but not of the wild type of strain. The most effective molecule was heteroscyphin $D$, which suppressed the ability of $C$. albicans to adhere to A549 cells and to form biofilms with a complete inhibiton at $8 \mu \mathrm{g} / \mathrm{mL}$, determined by XTT assay. In addition, this compound was able to modulate the transcription of related genes in this fungus, as described in Table 4. Das et al. [158] showed that artemisinin (Ar), the sesquiterpene lactone isolated from Artemisia annua L. (Asteraceae), and scopoletin (Sc), the 7-hydroxy-6-methoxy coumarin present in several spp., were tested on mature biofilms of different albicans and non-albicans Candida strains. The results demonstrated that Ar was more active than Sc in disrupting the preformed EPM-covered biofilm structure and in killing the sessile cell population at their respective $\mathrm{MBEC}_{10}$. In the same year, Lemos et al. [159] demonstrated that Sc, at its MIC $(50 \mu \mathrm{g} / \mathrm{mL})$, was able to reduce the preformed biofilms of a resistant $C$. tropicalis strain in $68.2 \%$, and to inhibit the biofilm formation. Kipanga et al. [160] showed that the drimane sesquiterpene dialdehydes warburganal and polygodial, obtained from Warburgia ugandensis Sprague (Canellaceae), inhibited C. albicans biofilm formation with $\mathrm{MBIC}_{50}$ of 4.5 and $10.8 \mu \mathrm{g} / \mathrm{mL}$, respectively, and with $\mathrm{MBIC}_{50}$ of 49.1 and $50.6 \mu \mathrm{g} / \mathrm{mL}$, respectively, against $C$. glabrata. Regarding biofilm eradication, warburganal and polygodial showed $\mathrm{MBEC}_{50}$ of 16.4 and $16.0 \mu \mathrm{g} / \mathrm{ml}$, respectively, against C. albicans but did not inhibit C. glabrata biofilm eradication. The higher potency of warburganal over polygodial for inhibiting biofilm formation and eradication could be attributed to the hydroxyl group present at position C-9, that differentiates both sesquiterpenes. The triterpenoid saponins gypenosides, isolated from Gynostemma pentaphyllum (Thunb.) Makino (Cucurbitaceae), showed $\mathrm{MBIC}_{80}>$ $128 \mu \mathrm{g} / \mathrm{mL}$ against two fluconazole-resistant strains of $C$. albicans, as determined by XTT. No significant reduction in the density and in the length of the hyphae were observed [161]. 
Zhao et al. [162] showed that turbinmicin, a highly functionalized polycyclic compound isolated from the marine microbiome, completely disrupted extracellular vesicle (EV) delivery, during biofilm growth at $16 \mu \mathrm{g} / \mathrm{mL}$, and this impaired the subsequent assembly of the biofilm EPM. C. albicans biofilm EVs have a pivotal role in EPM production and biofilm drug resistance [163]. This property was observed by a combination of flow cytometry, image confirmation, and fluorescence sensitivity on C. albicans, C. tropicalis, C. glabrata, C. auris and A. fumigatus. By SEM, it was determined that turbinmicin at $2.5 \mu \mathrm{g} / \mathrm{mL}$ eliminated EPM, thus rendering the drug-resistant biofilm communities susceptible to the antifungal effects of TBM itself, as well as to clinical antifungal agents. Zainal et al. [164] demonstrated that allicin, the organosulfur compound obtained from Allium sativum L. (Amaryllidaceae), was able to eradicate $50 \%$ of $C$. albicans biofilm formed on self-polymerized acrylic resin when administered at a sub-MIC concentration of $4 \mu \mathrm{g} / \mathrm{mL}$. Feldman et al. [165] reported that cannabidiol (CBD) obtained from Cannabis sativa L. (Cannabaceae) exerted an inhibitory effect on biofilm formation with a MBIC $_{90}$ of $100 \mu \mathrm{g} / \mathrm{mL}$. At $25 \mu \mathrm{g} / \mathrm{mL}$, the metabolically active cells (assessed by MTT) in 24, 48 and $72 \mathrm{~h}$-biofilms decreased by $48 \%, 64 \%$ and $87 \%$, respectively. At 1.56 and $3.12 \mu \mathrm{g} / \mathrm{mL}$, mature biofilms decreased by $28 \%$ and $44 \%$, respectively. Furthermore, CBD reduced the thickness of fungal biofilm and EPM production accompanied by a downregulation of genes involved in EPM synthesis. At $25 \mu \mathrm{g} / \mathrm{mL}, \mathrm{CBD}$ inhibited $90 \%$ of the ATP synthesis and enhanced mitochondrial membrane potential and ROS levels. At $\frac{1}{4} \mathrm{MBIC}_{90}$, CBD produced upregulation of yeast-associated genes and downregulation of hyphae-specific genes. As reported by Ivanov et al. [166], camphor inhibited more than $50 \%$ of the biofilm biomass in C. albicans strains at $62-250 \mu \mathrm{g} / \mathrm{mL}$, while in C. tropicalis, the inhibition was achieved at $175 \mu \mathrm{g} / \mathrm{mL}$. On the other hand, eucalyptol showed the same effect in the tested $C$. albicans strains at higher concentrations $(>3000 \mu \mathrm{g} / \mathrm{mL}$ ) and in C. tropicalis, C. parapsilosis and C. krusei at $>1000 \mu \mathrm{g} / \mathrm{mL}$ [166]. Camphor, applied at $125 \mu \mathrm{g} / \mathrm{mL}$, reduced ROS generation in one strain of C. albicans, although eucalyptol failed to exert this effect. The compounds did not interfere with ERG11 expression. Neosartorya fifischeri antifungal protein 2 (NFAP2), a novel member of small cysteine-rich and cationic antifungal proteins from filamentous ascomycetes (crAFPs), showed low activity against $C$. auris biofilms [167]. When NFAP2 was tested in combination with clinical antifungals, an enhancement of the activity was observed. The results of combinations were not included in this review. 
Table 4. More relevant results of natural compounds showing a capacity for inhibiting fungal biofilms.

\begin{tabular}{|c|c|c|c|c|c|c|c|c|}
\hline $\begin{array}{lll}\text { Year } \\
\end{array}$ & Type of Compound/Natural Source & $\begin{array}{l}\text { Structure and Name } \\
\end{array}$ & Strains & $\begin{array}{l}\text { In Vitro Type of Studies } \\
\text { Inhibition of Cell Adhesion } \\
\text { or Hyphal Formation } \\
\end{array}$ & Biofilm Formation & $\begin{array}{l}\begin{array}{l}\text { Eradication of Mature } \\
\text { Biofilms }\end{array} \\
\end{array}$ & $\begin{array}{l}\text { Studies of Mechanisms of } \\
\text { Action }\end{array}$ & Reference \\
\hline 2017 & $\begin{array}{l}\text { Formyl-phloroglucinol meroterpenoid } \\
\text { Source } \\
\text { Eucalyptus spp. and Psidium spp. }\end{array}$ & eucarobustol E (EI & 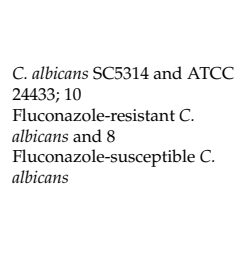 & $\begin{array}{l}\text { EE inhibited C. albicans } \\
\text { yeast-to-hyphal transition in } \\
\text { both liquid and solid } \\
\text { hypha-inducing media }\end{array}$ & $\begin{array}{l}\text { EE inhibited } 60 \text { and } 73 \% \\
\text { biofilm formation at } 16 \text { and } \\
32 \mu \mathrm{mg} / \mathrm{mL} \text {, erppectively and } \\
100 \% \text { at }>32 \mathrm{\mu g} / \mathrm{mL}\end{array}$ & $\begin{array}{l}\text { EE eradicated mature biofilm } \\
\text { at } 128 \mathrm{\mu g} / \mathrm{mL}\end{array}$ & $\begin{array}{l}\text { At } 8 \text { and } 16 \mu \mathrm{gg} / \mathrm{ml} \mathrm{EE} \\
\text { reduced by } 9.2 . \% \text { and } 65.3 \% \\
\text { the ergosterol production } \\
\text { and increased by } 3.35 \text {-and } \\
5.43 \text {-fold the farnesol } \\
\text { production, respectively }\end{array}$ & [145] \\
\hline 2017 & $\begin{array}{l}\text { Isoquinoline alkaloid } \\
\text { Source } \\
\text { Not informed }\end{array}$ & & 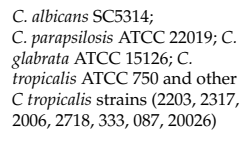 & $\begin{array}{l}\text { BBR inhibited Candida } \\
\text { biofilm formation with MBIC } \\
\text { values of } 64-256 \mu \mathrm{gg} / \mathrm{mL}\end{array}$ & & & & [146] \\
\hline 2017 & $\begin{array}{l}\text { 3-3'-Neolignan } \\
\text { Source } \\
\text { Magnolia officinalis }\end{array}$ & & $\begin{array}{l}\text { C. dubliniensis CDC 27897; C. } \\
\text { albicans CDC 27907 and } \\
\text { ATCC } 244333 \text { C. glabrata CDC } \\
28621\end{array}$ & & & $\begin{array}{l}\text { Magnolol inhibited } \\
35.6 \% \text { - } 69.5 \% \text { preformed } \\
\text { biofilims of the three fungi at } \\
32 \mathrm{\mu g} / \mathrm{mL}\end{array}$ & & [147] \\
\hline \multirow[t]{2}{*}{2017} & \multirow[t]{2}{*}{$\begin{array}{l}5 \text { terpenes and one phenylpropanoid. } \\
\text { Sources. } \\
\text { EOs from Origanum vulgare, Mentha piperita, } \\
\text { Thymus sulgaris Cinamomum verum } \\
\text { Cymbopogon citratus and Syzyyium aromaticum }\end{array}$} & $\begin{array}{l}\mathrm{H}_{3} \mathrm{C}^{-} \\
\text {thymol }\end{array}$ & $\begin{array}{l}\text { C. neeformans NCIM } 3541 \text { and } \\
\text { C. laurentiti NCIM } 3373\end{array}$ & & $\begin{array}{l}\text { MBIC } 8 \text { against C. } \\
\text { neoformans and C. laurentii: } \\
\text { for thymol: } 22 \text { and } 16 \\
\mu \mathrm{g} / \mathrm{mL} ; \text { for carvacrol, } 64 \text { and } \\
32 \mu \mathrm{mL} \text { and for citral, } 128\end{array}$ & $\begin{array}{l}\mathrm{MBEC}_{80} \text { of thymol and } \\
\text { carvacrol against } \mathrm{C} \text {. } \\
\text { neoformans were } 128 \text { and } 256 \\
\mu \mathrm{g} / \mathrm{mL} \text {, respectively, and } \\
\text { against C. laurentii } 64 \text { and } 128\end{array}$ & $\begin{array}{l}\text { The compounds reduced } \\
\text { EPM, cellular density and } \\
\text { altered the surface } \\
\text { morphology of biofilm cells }\end{array}$ & \multirow[t]{2}{*}{ [148] } \\
\hline & & & & & & $\begin{array}{l}\mathrm{MBEC} \mathrm{C}_{80} \text { for citral was } 256 \\
\mu \mathrm{g} / \mathrm{mL} \text { for both fungi }\end{array}$ & & \\
\hline
\end{tabular}


Table 4. Cont.

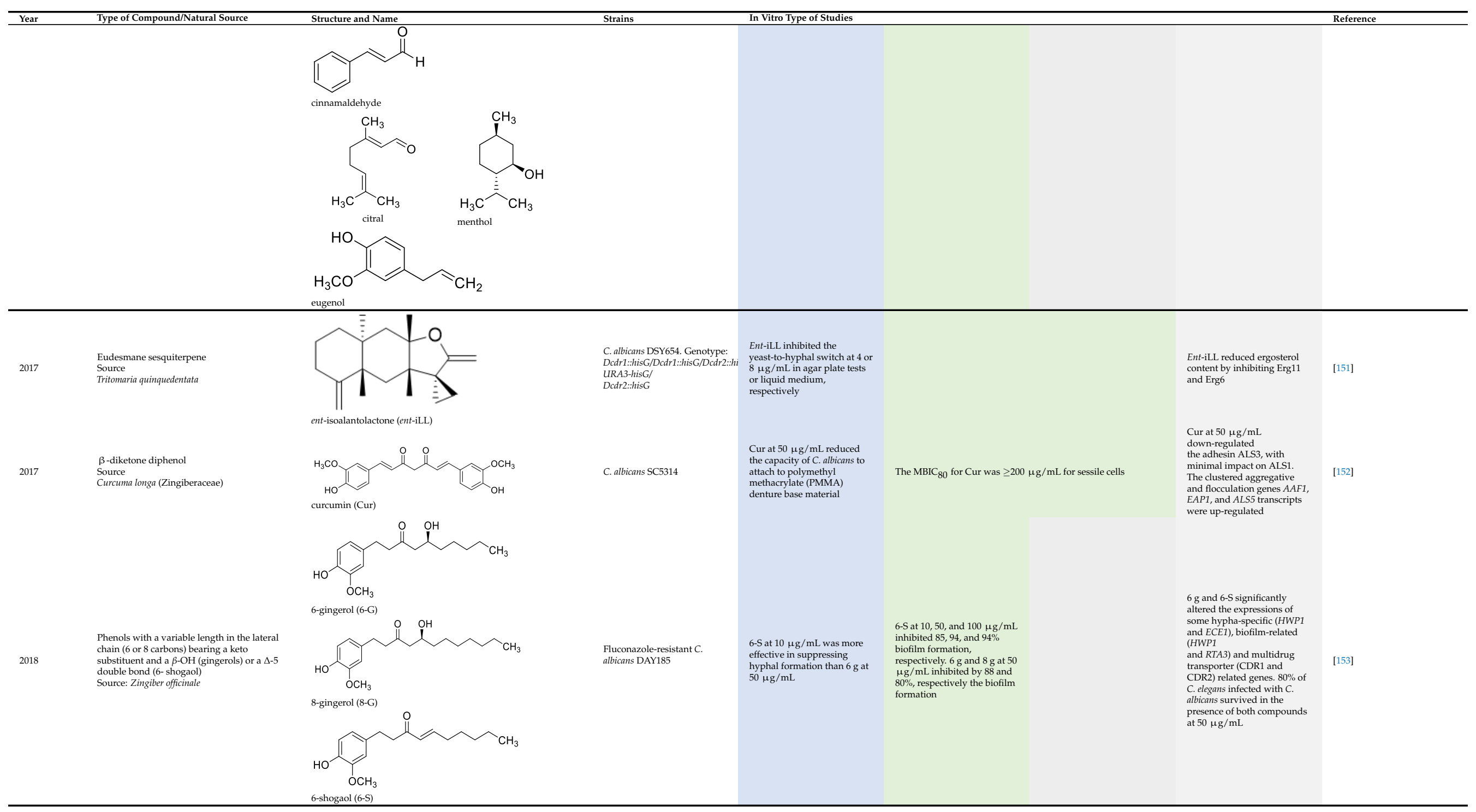


Table 4. Cont.

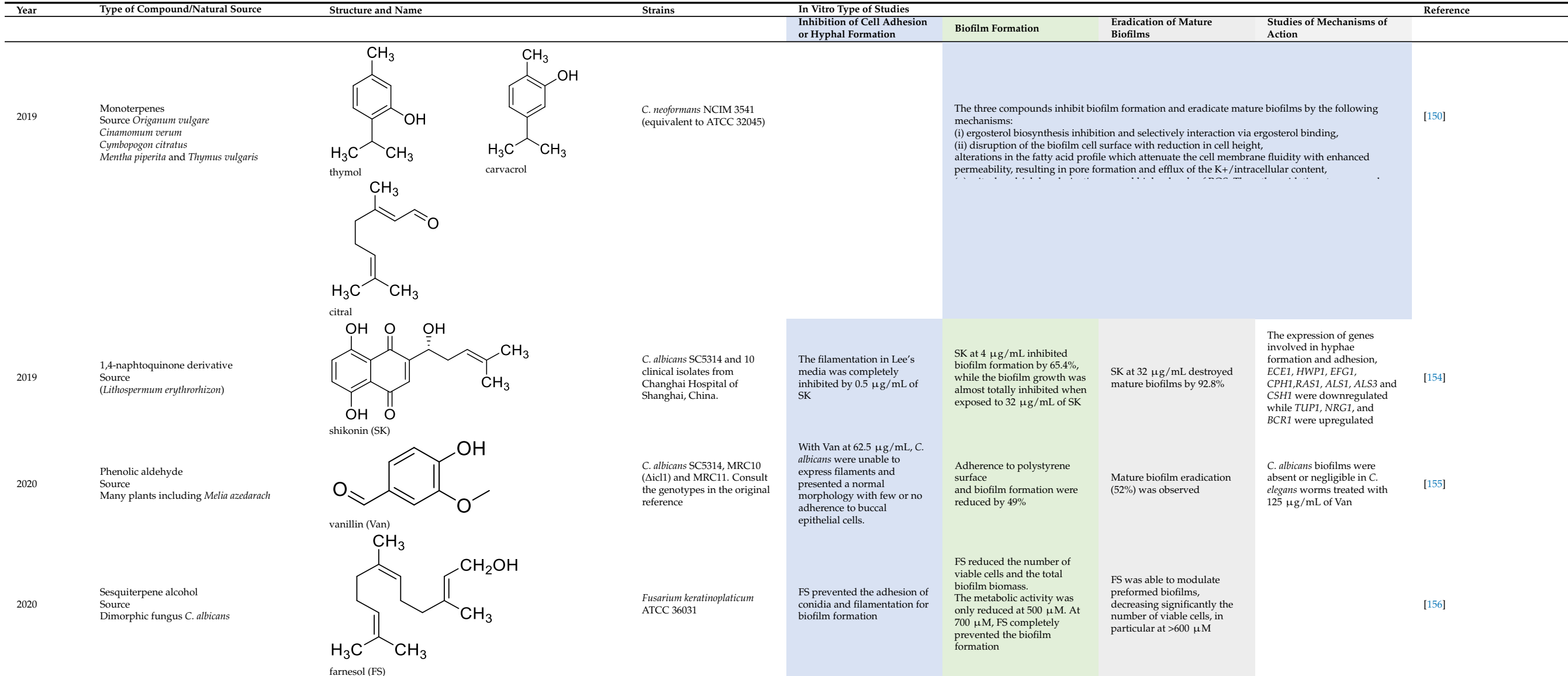


Table 4. Cont.

\begin{tabular}{|c|c|c|c|c|c|c|c|c|}
\hline $\begin{array}{l}\text { Year } \\
\end{array}$ & Type of Compound/Natural Source & & Strains & & & & & Reference \\
\hline & & & & $\begin{array}{l}\text { Inhibibition of cell Addhesion } \\
\text { or Hyphal Formation }\end{array}$ & Biofilm Formation & $\begin{array}{l}\text { Eradicatition of Mature } \\
\text { Biofilms }\end{array}$ & $\begin{array}{l}\text { Studies of Mechanisms of } \\
\text { Action }\end{array}$ & \\
\hline 2020 & $\begin{array}{l}\text { Labdane diterpenoid } \\
\text { Source } \\
\text { liverwort Heteroscyphus } \\
\text { coalitus }\end{array}$ & & $\begin{array}{l}\text { CDR1 and CDR2 efflux } \\
\text { pumps deficient strain C. } \\
\text { albicans DSYY544 and the wild } \\
\text { type C. albicans S5314 }\end{array}$ & 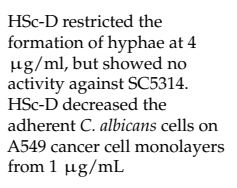 & $\begin{array}{l}\text { HSc-D completely prevented } \\
\text { biofilm formation at } \\
\geq 8 \mathrm{\mu g} / \mathrm{mL}\end{array}$ & & 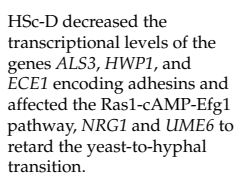 & [157] \\
\hline 2020 & $\begin{array}{l}\text { Artemisinin sesquiterpene lactone } \\
\text { Scopoletin: coumarin derivative } \\
\text { Sources } \\
\text { Ar: Artemisiaunnua } \\
\text { Sc: from several plants including A. annua }\end{array}$ & $\begin{array}{r}\text { artemisin } \\
\mathrm{HO}\end{array}$ & $\begin{array}{l}\text { C. albicans 1372; } \\
\text { C. dubliniensis 1470, C. } \\
\text { tropicalis } 1368, \\
\text { C. krusei } 779, \\
\text { C. glabrata } 1374 \text { and } \\
\text { C. guilliermondii } 808\end{array}$ & & $\begin{array}{l}\text { FS and Sc reduced biofilm } \\
\text { biomass and metabolic } \\
\text { activity and led to non-viable } \\
\text { cells }\end{array}$ & 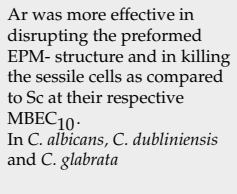 & $\begin{array}{l}\text { Ar and Sc promoted the } \\
\text { accumulation of intracellular } \\
\text { ROS by increasing oxidative } \\
\text { stress at their respective } \\
\text { MBEC }\end{array}$ & [158] \\
\hline 2020 & $\begin{array}{l}\text { Scopoletin: coumarin derivative } \\
\text { Source } \\
\text { Mitracarpus frigidus. }\end{array}$ & & $\begin{array}{l}\text { Fluconazole, itraconazol and } \\
\text { amphothericin-resistant C. } \\
\text { tropicalis ACCC } 28707\end{array}$ & & $\begin{array}{l}\text { At } 4 \times \text { MIC }(200 \mu \mathrm{g} / \mathrm{mL}), \mathrm{Sc} \\
\text { produced a great reduction of } \\
\text { the area occupied by biofilms } \\
\text { on the surface of coverslips }\end{array}$ & $\begin{array}{l}\text { At its MIC }(50 \mu \mathrm{g} / \mathrm{mL}), \mathrm{Sc} \\
\text { reduced preformed Candida } \\
\text { biofilms }\end{array}$ & & [159] \\
\hline 2020 & $\begin{array}{l}\text { Drimane sesquiterpene dialdehydes } \\
\text { Source } \\
\text { Warburgia ugandensis }\end{array}$ & $\begin{array}{r}\mathrm{H}_{3} \mathrm{C} \quad \mathrm{CH} \\
\text { (+)-warburganal } 1 \\
\text { (-)-polygodial } \mathrm{R}=\end{array}$ & 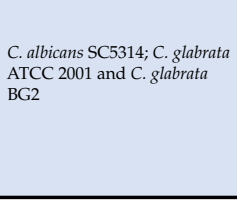 & & 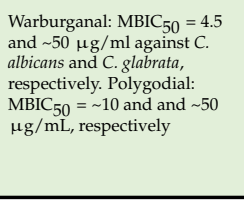 & 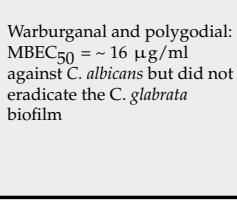 & & [160] \\
\hline
\end{tabular}


Table 4. Cont.

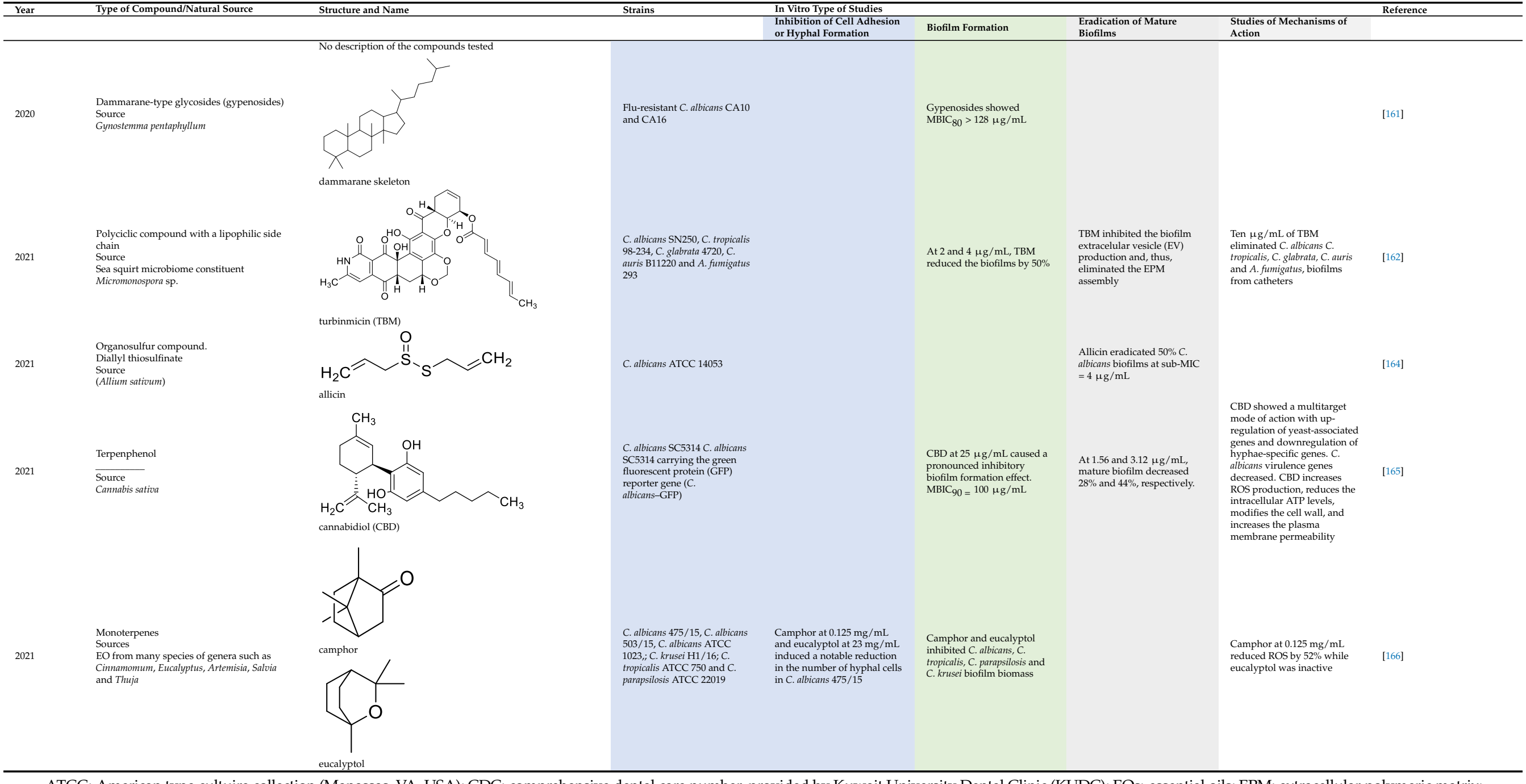

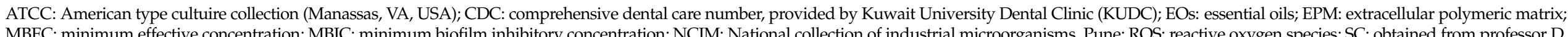

Sanglard, Centre Hospitalier Universitaire Vaudois, Lausanne, Switzerland; SMIC: sessile minimum inhibitory concentration. Other culture collection acronyms can be found in the respective reference. 
Although the main objetive of this review is to provide published data on the in vitro or in vivo antibiofilm activity of natural products, mention should be made to the method reviewed by Jha et al., 2020 [17]. These authors performed a multiple target-based structural bioinformatic study to recognize molecules that have the capacity of targeting proteins with a vital role in wall synthesis (FKS2 and FKS1), ergosterol synthesis (ERG11, ERG1, ERG24 and ERG3), and drug transport, such as Flu1 and the kinases CST20, HST7 and CEK1 involved in CHP1 pathway. The Cph1 transcription factor is involved in biofilm and pseudohyphae formation [168]. According to the results obtained, 2-O-prenylcoumaric, acid, 4-coumaryl acetate, coniferaldehyde, coniferyl alcohol, cycloserinehybrid and 2coumaric acid targeted all proteins, while 110 molecules bound to at least four of them [17]. Among the evaluated compounds, vanillin showed interactions with ERG11, ERG1, ERG24, FKS2, CST20, HST7 and CEK1 while BBR targeted all of these proteins except Flu1 [17]. Thymol interacted to all proteins, except ERG24 and ERG1, and carvacrol bound to ERG24, ERG1 HST7, CST20, CEK1 and Flu1. Likewise, eugenol targeted ERG24, ERG1, FKS1, FKS2, FUR1 and Flu1 and cinnamaldehyde interacted with all of the proteins except FKS1, FKS2, FUR1 and Flu1. These data would explain, at least in part, the antibiofilm activity of the mentioned small molecules, which has been reported above and also in Table 4 , while opening the possibility to test experimentally the effects on biofilms of the rest of the ligands.

\section{Reported Antibiofilm Activities of Nanosystems Containing Natural Products}

The published literature related to the antibiofilm properties of nanosystems are shown in Table 5. Quatrin et al. [169] prepared nanoemulsions (NE) containing 5\% E. globulus EO and $2 \%$ sorbitan monooleate (Span 80) with the aqueous phase containing $2 \%$ Tween 80 . EO-NE were tested for their capacity to inhibit biofilm formation of three Candida spp. in high density polyethylene substrates. EO-NE at $22.5 \mathrm{mg} / \mathrm{mL}$ reduced C. albicans, C. tropicalis and C. glabrata biofilm formation by $84.5 \%, 61.3 \%$ and $84 \%$, respectively. The biofilms were quantified by $\mathrm{CV}$ staining and corroborated by ATM and the fluorescence $\mathrm{CW}$ technique.

Due to $M$. alternifolia EO (tea tree oil (TTO)) showed antibiofilm activity against C. albicans spp. in previous studies but possesses poor solubility and high volatility [170], Souza et al. [171] prepared TTO-nanoparticles and tested them against C. albicans, C. glabrata, C. parapsilopsis, C. membranafaciens and C. tropicalis biofilms. The results obtained showed that TTO and TTO-nanoparticles decreased by $67 \%$ and $72 \%$ respectively the C. albicans and C. glabrata biofilm biomass visualized with $\mathrm{CV}$ and confirmed by $\mathrm{CW}$ and ATM. The antibiofilm activity was more evident against C. glabrata. TTO-NP decreased EPM and proteins in biofilms and, therefore, TTO-NP can penetrate more easily through the EPM, releasing the TTO into the biofilm and resulting in a better antimicrobial activity. TTO-NPs can disturb the fungal membrane by blocking the respiratory chain through the inhibition of the enzyme succinate dehydrogenase of the internal fungal cell mitochondrial membrane. 
Table 5. Nanososystems containing natural products.

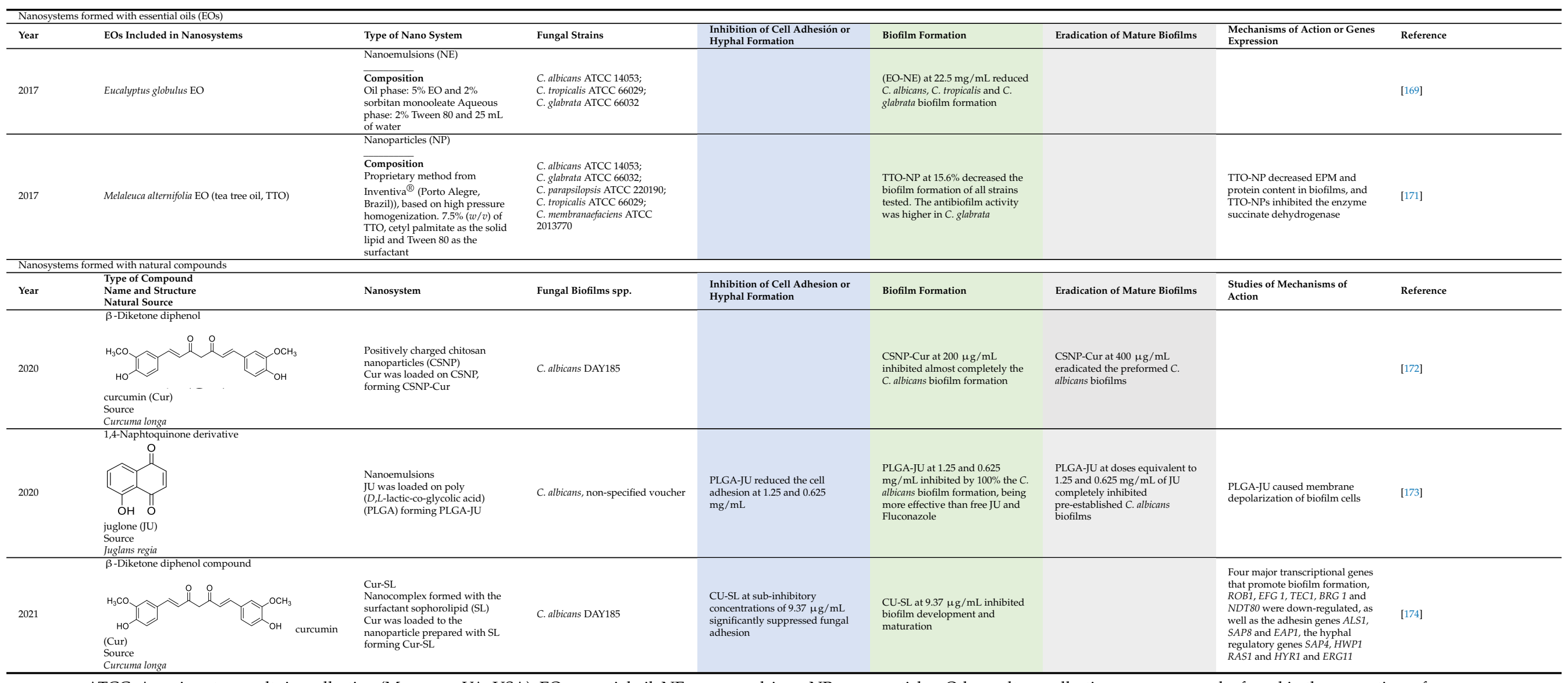

ATCC: American type cultuire collection (Manassas, VA, USA); EO: essential oil; NE: nanoemulsions; NP: nanoparticles. Other culture collection acronyms can be found in the respective reference. 
Considering that free Cur at $200 \mu \mathrm{g} / \mathrm{mL}$ inhibited almost completely the C. albicans biofilm formation, Ma et al. [172] prepared Cur-chitosan nanoparticles (CSNP). However, CSNP-Cur exhibited a slightly less inhibitory effect than free Cur. On the contrary, $400 \mu \mathrm{g} / \mathrm{mL}$ of CSNP-Cur eradicated the preformed C. albicans biofilms by $91.38 \%$, being more effective than free Cur. SEM and CLSM showed that CSNP-Cur reduced polymicrobial biofilm thickness as well as killed microbial cells embedded in biofilms on silicone surfaces. In a recent paper, Gumus et al. [173] prepared nanoparticles of juglone (JU) encapsulated in poly D,L-lactic-co-glycolic acid (PLGA). As determined by plate count technique, these PLGA-JU nanoparticles completely inhibited biofilm formation and pre-established biofilms, at doses equivalent to 1.25 and $0.625 \mathrm{mg} / \mathrm{mL}$ of JU, respectively, whereas fluconazole did not cause a significant inhibition, even at the highest dose applied $(10 \mathrm{mg} / \mathrm{mL})$. PLGA-JU were more active than free JU and fluconazole. The inhibition of biofilm formation seems to be due to PLGA-JU reducing the cell adhesion, and the number of viable cells and altered membrane structures at both mentioned doses.

Rajasekar et al. [174] synthesized a nanocomplex formed by the surfactant sophorolipid (SL) derived from non pathogenic yeasts such as Starmerella / Candida bombicola and Cur, and tested it against $C$. albicans biofilms. Sub-inhibitory concentrations of Cur-SL $(9.37 \mu \mathrm{g} / \mathrm{mL})$ significantly decreased fungal adhesion to glass coverslips, as well as biofilm development, maturation, and filamentation. Concomitantly, a significant downregulation of a select group of biofilm adhesins and hyphal regulatory genes was observed.

\section{Discussion}

In this review, the natural products that demonstrated activity against fungal biofilms from 2017 to May 2021 were collected, with the aim of offering an overview of the progress made in this area to curb difficult-to-eradicate fungal infections. The type of natural products that showed better antibiofilm activities, the fungal species of the target biofilms, the type of assays used and the mechanisms of action were analyzed in order to detect the advances performed in this period that can be the basis of future works.

Regarding the type of natural products that showed antibiofilm activities, 17 of the 42 manuscripts involved natural mixtures such as EOs (seven manuscripts) propolis (two manuscripts) or extracts prepared with solvents (total eight manuscripts), six of them from plants, one from lichens and one from microalgae or cyanobacteria. Two papers dealt with nanosystems including EOs. The antibiofilm activities of the seven EOs do not add a great novelty to the already known antibiofilm activity of these products. However, the nanosystems prepared with EOs open a great avenue for further research. In addition, the paper authored by Quatrin et al. [169], which tested a nanosystem with E. gobulus EO (EO-NE), not only used C. albicans as in most publications on antibiofilm EOs, but also used C. tropicalis, C. glabrata and C. auris although the EO-NE was devoid of activity in the latter sp. [169]. Considering that $C$. glabrata is a fungus intrinsically resistant to most antifungal drugs [175], the activity found against this fungus is encouraging for further research. With respect to extracts obtained with solvents from different spp., no preference for a botanical family was observed, and in most cases the antibiofilm activities should be deepened since the mechanism to achieve this effect was not analyzed.

Twenty three of the 42 retrieved articles tested pure natural compounds, twenty of them alone and three included in nanosystems. Regarding the main type of pure compounds that showed a capacity for inhibiting biofilms on its own, nine of them were terpenes with four monoterpenes derivatives, four sesquiterpenes and one diterpene, which is in accordance with previous reports [124]. Two manuscripts studied the coumarin Sc, and one evaluated dammarane-type glycosides (gypenosides). A phloroglucinol, an alkaloid, a neolignan and some diphenols were investigated along with four compounds belonging to other types of chemical families. Cur was included in two nanosystems. Most of the compounds (21 compounds) were derived from plants, with one compound obtained from fungi (farnesol) and one obtained from a sea squirt microbiome (turbinmicin). 
With respect to the fungal spp. tested in the 42 papers included in this review, 38 of these involved Candida spp. biofilms, two comprised Fusarium spp., two involved Cryptococcus spp. and one, A. fumigatus plus Candida spp. Among Candida biofilms, 23 studies included only C. albicans and 12 used different non-albicans Candida spp., but also involved C. albicans. Two papers used only C. tropicalis biofilms. Unfortunately, only two papers used C. auris among the non-albicans Candida spp. The newly described yeast C. auris has emerged as a resistant fungal pathogen responsible for hospital outbreaks, especially in intensive care units [176], leading to high mortality rates [177]. C. auris is at present a worrisome healthcare problem and new antifungals that overcome its resistance are highly needed [177]. The protein NFAP2 and the highly functionalized polycyclic turbinmicin completely disrupted EV delivery during C. auris biofilm growth [164]. Turbinmicin also showed activity against $A$. fumigatus biofilms.

Regarding anti-C. neoformans and C. laurentii biofilms, only thymol, carvacrol and citral proved to be effective for inhibiting the formation and eradication of the mentioned biofilms; however, importantly, their mechanisms of action were studied [150,152]. These are significant findings, since this fungus can colonize the central nervous system, highlighting its significance as a critical pathogenic yeast.

Propolis from Brazil and farnesol were the sole natural samples which showed a capacity for inhibiting Fusarium spp. This mold causes mildly superficial to fatally disseminated fungal infections, being the second most common mold causing opportunistic invasive infections after Aspergillus [178]. Keratitis is still the most common infection produced by Fusarium spp. [75,179]. The 2005-2006 outbreak of keratitis due to contact lens infections was attributed partly to the ability of F. keratitis to form biofilms $[180,181]$.

Regarding the type of tests performed, most papers used only in vitro assays. Of them, twelve articles studied the inhibition of cell-to-hyphal transition or cell adhesion, 31 reported inhibition of biofilm formation, and 25 described eradication capacity.

It is worth taking into account that for the antibiofilm compounds to be useful in clinics, it is crucial to determine whether a drug is able to penetrate and eradicate the pre-formed biofilms [102]. The fact that the reported works have not assessed the biofilm eradication capacity but only inhibitory effects on biofilm formation might contribute to a poor correlation between biofilm susceptibility and clinical outcomes.

Only 15 papers deepened the study by giving evidence of the mechanisms of action. Of them, 11 were performed with pure compounds, three with nanosystems, and only one with an extract. It is important to highlight that sometimes the mechanisms of antibiofilm action were demonstrated to be multifactorial $[150,182]$.

Only five of the 42 analyzed papers used in vivo assays, of which four were performed with C. elegans and only one, used rats. This is worrying since animal models of Candida biofilm infections are relevant for identifying novel antifungals useful in clinics [105].

\section{Conclusions and Perspectives}

From 2017 to May 2021, there has been an active research on natural products with antifungal biofilm activity. It is clear that great progress has been made and that the newly discovered natural antibiofilm agents could provide novel agents for biofilm-associated infections. Of them, the protein NFAP2 and the highly functionalized polycyclic turbinmicin have demonstrated interesting antibiofilm properties and deserve further research.

However, several types of studies must be deepened. For example, fungal biofilms different from those of Candida spp. should be prepared and used as targets. Among them, it is necessary to investigate the behavior of natural samples on filamentous fungal biofilms, which are scarcely studied in comparison to Candida spp. such as those of the genera Aspergillus, Fusarium and Trichophyton [183,184].

To be useful for future development, all papers should analyze biofilm eradication capacities in addition to the study of the inhibition of biofilm formation and other properties. Besides, in vivo assays should be included in all papers dealing with activity against biofilms. 
It is worth taking into account that several clinical trials involving natural antibiofilm agents are in progress, and some of them exhibited promising perspectives, as recently reviewed by Lu et al. [185].

\section{Materials and Methods}

The search for suitable papers was performed in electronic databases by using the following keywords: "biofilm", "fungal infections", "sessile cells", "secondary metabolites", "natural products", "repurposing", "antifungal drugs", and "antibiofilm". Additional papers matching the search criteria were included after surveying the references from the selected articles.

The information gathered was divided into three groups: (I) natural extracts including EOs, propolis and extracts from plants, lichens, algae and cyanobacteria, (II) pure natural compounds, and (III) nanosystems. This last section was sub-divided by EOs included in nanosystems and pure natural compounds included in nanosystems.

Author Contributions: Conceptualization, S.Z.; methodology, E.B., L.S., M.C.C. and T.E.; formal analysis, S.Z., M.C.C., T.E.; investigation, S.Z., E.B., L.S., M.C.C. and T.E.; resources, S.Z., L.S.; writing-review and editing, S.Z., M.C.C., T.E.; funding acquisition, S.Z., L.S., M.C.C., T.E. All authors have read and agreed to the published version of the manuscript.

Funding: This research was funded by ANPCyT (PICT 2017-1381, PICT 2018-02034 and PICT 201900721); ASaCTeL (IO-2019-139); UNR (8002019030001UR) and Universidad Católica de Córdoba.

Conflicts of Interest: The authors declare no conflict of interest.

\section{References}

1. Pathakumari, B.; Liang, G.; Liu, W. Immune defence to invasive fungal infections: A comprehensive review. Biomed. Pharmacother. 2020, 130, 110550. [CrossRef]

2. Wuyts, J.; Van Dijck, P.; Holtappels, M. Fungal persister cells: The basis for recalcitrant infections? PLoS Path. 2018, 14, e1007301. [CrossRef] [PubMed]

3. Nicola, A.M.; Albuquerque, P.; Paes, H.C.; Fernandes, L.; Costa, F.F.; Kioshima, E.S.; Abadio, A.K.R.; Bocca, A.L.; Felipe, M.S. Antifungal drugs: New insights in research \& development. Pharmacol. Ther. 2019, 195, 21-38. [PubMed]

4. Kullberg, B.J.; Vasquez, J.; Mootsikapun, P.; Nucci, M.; Paiva, J.-A.; Garbino, J.; Yan, J.L.; Aram, J.; Capparella, M.R.; Conte, U. Efficacy of anidulafungin in 539 patients with invasive candidiasis: A patient-level pooled analysis of six clinical trials. J. Antimicrob. Chemother. 2017, 72, 2368-2377. [CrossRef] [PubMed]

5. Bongomin, F.; Gago, S.; Oladele, R.O.; Denning, D.W. Global and multi-national prevalence of fungal diseases-Estimate precision. J. Fungi 2017, 3, 57. [CrossRef]

6. Prasad, R.; Nair, R.; Banerjee, A. Multidrug transporters of Candida species in clinical azole resistance. Fungal Genet. Biol. 2019, 132, 103252. [CrossRef] [PubMed]

7. Arastehfar, A.; Gabaldón, T.; Garcia-Rubio, R.; Jenks, J.D.; Hoenigl, M.; Salzer, H.J.F.; Ilkit, M.; Lass-Flörl, C.; Perlin, D.S. Drugresistant fungi: An emerging challenge threatening our limited antifungal armamentarium. Antibiotics 2020, 9, 877. [CrossRef] [PubMed]

8. Di Mambro, T.; Guerriero, I.; Aurisicchio, L.; Magnani, M.; Marra, E. The yin and yang of current antifungal therapeutic strategies: How can we harness our natural defenses? Front. Pharmacol. 2019, 10, 80. [CrossRef]

9. Wu, S.; Wang, Y.; Liu, N.; Dong, G.; Sheng, C. Tackling fungal resistance by biofilm inhibitors. J. Med. Chem. 2017, 60, $2193-2211$. [CrossRef]

10. Pfaller, M.A.; Diekema, D.J. Epidemiology of invasive candidiasis: A persistent public health problem. Clin. Microbiol. Rev. 2007, 20, 133-163. [CrossRef]

11. Borjian Boroujeni, Z.; Shamsaei, S.; Yarahmadi, M.; Getso, M.I.; Salimi Khorashad, A.; Haghighi, L.; Raissi, V.; Zareei, M.; Saleh Mohammadzade, A.; Moqarabzadeh, V.; et al. Distribution of invasive fungal infections: Molecular epidemiology, etiology, clinical conditions, diagnosis and risk factors: A 3-year experience with 490 patients under intensive care. Microb. Pathog. 2021, 152, 104616. [CrossRef] [PubMed]

12. McCarthy, M.W.; Walsh, T.J. Drug development challenges and strategies to address emerging and resistant fungal pathogens. Expert Rev. Anti Infect. Ther. 2017, 15, 577-584. [CrossRef]

13. Wall, G.; Lopez-Ribot, J.L. Current antimycotics, new prospects, and future approaches to antifungal therapy. Antibiotics 2020, 9, 445. [CrossRef] [PubMed]

14. Enoch, D.A.; Yang, H.; Aliyu, S.H.; Micallef, C. The Changing Epidemiology of Invasive Fungal Infections; Lion, T., Ed.; Humana Press: New York, NY, USA, 2017; Volume 1508, pp. 17-65.

15. Campoy, S.; Adrio, J.L. Antifungals. Biochem. Pharmacol. 2017, 133, 86-96. [CrossRef] [PubMed] 
16. Gintjee, T.J.; Donnelley, M.A.; Thompson, G.R. Aspiring antifungals: Review of current antifungal pipeline developments. J. Fungi 2020, 6, 28. [CrossRef]

17. Jha, A.; Vimal, A.; Kumar, A. Target shortage and less explored multiple targeting: Hurdles in the development of novel antifungals but overcome/addressed effectively through structural bioinformatics. Brief. Bioinform. 2021, 22, bbaa343. [CrossRef]

18. Grela, E.; Piet, M.; Luchowski, R.; Grudzinski, W.; Paduch, R.; Gruszecki, W.I. Imaging of human cells exposed to an antifungal antibiotic amphotericin B reveals the mechanisms associated with the drug toxicity and cell defence. Sci. Rep. 2018, 8, 1-7. [CrossRef]

19. Grela, E.; Wieczór, M.; Luchowski, R.; Zielinska, J.; Barzycka, A.; Grudzinski, W.; Nowak, K.; Tarkowski, P.; Czub, J.; Gruszecki, W.I. Mechanism of binding of antifungal antibiotic amphotericin B to lipid membranes: An insight from combined single-membrane imaging, microspectroscopy, and molecular dynamics. Mol. Pharm. 2018, 15, 4202-4213. [CrossRef]

20. Grela, E.; Zdybicka-Barabas, A.; Pawlikowska-Pawlega, B.; Cytrynska, M.; Wlodarczyk, M.; Grudzinski, W.; Luchowski, R.; Gruszecki, W.I. Modes of the antibiotic activity of amphotericin B against Candida albicans. Sci. Rep. 2019, 9, 1-10. [CrossRef]

21. Silva, L.N.; Oliveira, S.S.; Magalhães, L.B.; Andrade Neto, V.V.; Torres-Santos, E.C.; Carvalho, M.D.; Pereira, M.D.; Branquinha, M.H.; Santos, A.L. Unmasking the amphotericin B resistance mechanisms in Candida haemulonii species complex. ACS Infect. Dis. 2020, 6, 1273-1282. [CrossRef]

22. Ellsworth, M.; Ostrosky-Zeichner, L. Isavuconazole: Mechanism of action, clinical efficacy, and resistance. J. Fungi 2020, 6, 324. [CrossRef] [PubMed]

23. Thomas, S.; Espeisse, O. Antimicrobial resistance. N. Engl. J. Med. 1994 2020, 17, 330-333.

24. Saunte, D.M.; Hare, R.K.; Jørgensen, K.M.; Jørgensen, R.; Deleuran, M.; Zachariae, C.O.; Thomsen, S.F.; Bjørnskov-Halkier, L.; Kofoed, K.; Arendrup, M.C. Emerging terbinafine resistance in Trichophyton: Clinical characteristics, squalene epoxidase gene mutations, and a reliable EUCAST method for detection. Antimicrob. Agents Chemother. 2019, 63, e01126-19. [CrossRef] [PubMed]

25. Łagowski, D.; Gnat, S.; Nowakiewicz, A.; Osińska, M.; Dylag, M. Intrinsic resistance to terbinafine among human and animal isolates of Trichophyton mentagrophytes related to amino acid substitution in the squalene epoxidase. Infection 2020, 48, 889-897. [CrossRef] [PubMed]

26. Nowosielski, M.; Hoffmann, M.; Wyrwicz, L.S.; Stepniak, P.; Plewczynski, D.M.; Lazniewski, M.; Ginalski, K.; Rychlewski, L. Detailed mechanism of squalene epoxidase inhibition by terbinafine. J. Chem. Inf. Model. 2011, 51, 455-462. [CrossRef] [PubMed]

27. Lima, S.L.; Colombo, A.L.; de Almeida Junior, J.N. Fungal cell wall: Emerging antifungals and drug resistance. Front. Microbiol. 2019, 10, 2573. [CrossRef] [PubMed]

28. Cortés, J.C.G.; Curto, M.-Á.; Carvalho, V.S.; Pérez, P.; Ribas, J.C. The fungal cell wall as a target for the development of new antifungal therapies. Biotechnol. Adv. 2019, 37, 107352. [CrossRef]

29. Khalifa, H.O.; Majima, H.; Watanabe, A.; Kamei, K. In vitro characterization of twenty-one antifungal combinations against echinocandin-resistant and-susceptible Candida glabrata. J. Fungi 2021, 7, 108. [CrossRef]

30. Bhattacharya, S.; Sae-Tia, S.; Fries, B.C. Candidiasis and mechanisms of antifungal resistance. Antibiotics 2020, 9, 312. [CrossRef]

31. Ueda, Y.; Tahara, Y.O.; Miyata, M.; Ogita, A.; Yamaguchi, Y.; Tanaka, T.; Fujita, K.-i. Involvement of a multidrug efflux pump and alterations in cell surface structure in the synergistic antifungal activity of nagilactone $\mathrm{E}$ and anethole against budding yeast Saccharomyces cerevisiae. Antibiotics 2021, 10, 537. [CrossRef] [PubMed]

32. Freitas e Silva, K.S.; C Silva, L.; Gonçales, R.A.; Neves, B.J.; Soares, C.; Pereira, M. Setting new routes for antifungal drug discovery against pathogenic fungi. Curr. Pharm. Des. 2020, 26, 1509-1520. [CrossRef]

33. Lee, Y.; Puumala, E.; Robbins, N.; Cowen, L.E. Antifungal drug resistance: Molecular mechanisms in Candida albicans and beyond. Chem. Rev. 2020, 121, 3390-3411. [CrossRef]

34. Caldeirão, A.C.M.; Araujo, H.C.; Tomasella, C.M.; Sampaio, C.; dos Santos Oliveira, M.J.; Ramage, G.; Pessan, J.P.; Monteiro, D.R. Effects of antifungal carriers based on chitosan-coated Iron oxide nanoparticles on microcosm biofilms. Antibiotics 2021, 10, 588. [CrossRef]

35. Cerqueira, F.; Maia, M.; Gabriel, C.; Medeiros, R.; Cravo, S.; Ribeiro, A.I.; Dantas, D.; Dias, A.M.; Saraiva, L.; Raimundo, L.; et al. Mechanism of antifungal activity by 5-aminoimidazole-4-carbohydrazonamide derivatives against Candida albicans and Candida krusei. Antibiotics 2021, 10, 183. [CrossRef]

36. Fuentefria, A.M.; Pippi, B.; Dalla Lana, D.F.; Donato, K.K.; de Andrade, S.F. Antifungals discovery: An insight into new strategies to combat antifungal resistance. Lett. Appl. Microbiol. 2018, 66, 2-13. [CrossRef] [PubMed]

37. Jenks, J.D.; Cornely, O.A.; Chen, S.C.A.; Thompson III, G.R.; Hoenigl, M. Breakthrough invasive fungal infections: Who is at risk? Mycoses 2020, 63, 1021-1032. [CrossRef]

38. Katragkou, A.; Roilides, E.; Walsh, T.J. Role of echinocandins in fungal biofilm-related disease: Vascular catheter-related infections, immunomodulation, and mucosal surfaces. Clin. Infect. Dis. 2015, 61, S622-S629. [CrossRef] [PubMed]

39. Fanning, S.; Mitchell, A.P. Fungal biofilms. PLoS Path. 2012, 8, e1002585. [CrossRef] [PubMed]

40. Tits, J.; Cammue, B.; Thevissen, K. Combination therapy to treat fungal biofilm-based infections. Int. J. Mol. Sci. 2020, 21, 8873. [CrossRef]

41. Oliveira, L.T.; Lopes, L.G.; Ramos, S.B.; Martins, C.H.G.; Jamur, M.C.; Pires, R.H. Fungal biofilms in the hemodialysis environment. Microb. Pathog. 2018, 123, 206-212. [CrossRef]

42. Rodrigues, M.E.; Gomes, F.; Rodrigues, C.F. Candida spp./bacteria mixed biofilms. J. Fungi 2020, 6, 5. [CrossRef] [PubMed] 
43. Hirota, K.; Yumoto, H.; Sapaar, B.; Matsuo, T.; Ichikawa, T.; Miyake, Y. Pathogenic factors in Candida biofilm-related infectious diseases. J. Appl. Microbiol. 2017, 122, 321-330. [CrossRef]

44. Mitchell, K.F.; Zarnowski, R.; Andes, D.R. Fungal super glue: The biofilm matrix and its composition, assembly, and functions. Plos Path. 2016, 12, e1005828. [CrossRef]

45. Al-Fattani, M.A.; Douglas, L.J. Biofilm matrix of Candida albicans and Candida tropicalis: Chemical composition and role in drug resistance. J. Med. Microbiol. 2006, 55, 999-1008. [CrossRef] [PubMed]

46. Zarnowski, R.; Westler, W.M.; Lacmbouh, G.A.; Marita, J.M.; Bothe, J.R.; Bernhardt, J.; Lounes-Hadj Sahraoui, A.; Fontaine, J.; Sanchez, H.; Hatfield, R.D. Novel entries in a fungal biofilm matrix encyclopedia. MBio 2014, 5, e01333-14. [CrossRef] [PubMed]

47. Rodrigues, C.F.; Henriques, M. Portrait of matrix gene expression in Candida glabrata biofilms with stress induced by different drugs. Genes 2018, 9, 205. [CrossRef] [PubMed]

48. Santos, C.R.; Costa, P.A.; Vieira, P.S.; Gonzalez, S.E.; Correa, T.L.; Lima, E.A.; Mandelli, F.; Pirolla, R.A.; Domingues, M.N.; Cabral, L. Structural insights into $\beta$-1, 3-glucan cleavage by a glycoside hydrolase family. Nat. Chem. Biol. 2020, 16, 920-929. [CrossRef]

49. Stoodley, P.; Sauer, K.; Davies, D.G.; Costerton, J.W. Biofilms as complex differentiated communities. Annu. Rev. Microbiol. 2002, 56, 187-209. [CrossRef]

50. Ramage, G.; Saville, S.P.; Thomas, D.P.; Lopez-Ribot, J.L. Candida biofilms: An update. Eukaryot. Cell 2005, 4, 633-638. [CrossRef]

51. Mayer, F.L.; Wilson, D.; Hube, B. Candida albicans pathogenicity mechanisms. Virulence 2013, 4, 119-128. [CrossRef]

52. Lohse, M.B.; Gulati, M.; Johnson, A.D.; Nobile, C.J. Development and regulation of single-and multi-species Candida albicans biofilms. Nat. Rev. Microbiol. 2018, 16, 19-31. [CrossRef] [PubMed]

53. Alim, D.; Sircaik, S.; Panwar, S.L. The significance of lipids to biofilm formation in Candida albicans: An emerging perspective. J. Fungi 2018, 4, 140. [CrossRef] [PubMed]

54. Pimentel de Barros, P.; Rossoni, R.D.; de Souza, C.M.; Scorzoni, L.; Fenley, J.D.C.; Junqueira, J.C. Candida biofilms: An update on developmental mechanisms and therapeutic challenges. Mycopathologia 2020, 185, 415-424. [CrossRef] [PubMed]

55. McCall, A.D.; Pathirana, R.U.; Prabhakar, A.; Cullen, P.J.; Edgerton, M. Candida albicans biofilm development is governed by cooperative attachment and adhesion maintenance proteins. NPJ Biofilms Microbiomes 2019, 5, 1-12. [CrossRef]

56. Eix, E.F.; Nett, J.E. How biofilm growth affects candida-host interactions. Front. Microbiol. 2020, 11, 1437. [CrossRef]

57. Uppuluri, P.; Acosta Zaldívar, M.; Anderson, M.Z.; Dunn, M.J.; Berman, J.; Lopez Ribot, J.L.; Köhler, J.R. Candida albicans dispersed cells are developmentally distinct from biofilm and planktonic cells. MBio 2018, 9, e01338-18. [CrossRef]

58. Wall, G.; Montelongo-Jauregui, D.; Bonifacio, B.V.; Lopez-Ribot, J.L.; Uppuluri, P. Candida albicans biofilm growth and dispersal: Contributions to pathogenesis. Curr. Opin. Microbiol. 2019, 52, 1-6. [CrossRef]

59. Mehmood, A.; Liu, G.; Wang, X.; Meng, G.; Wang, C.; Liu, Y. Fungal quorum-sensing molecules and inhibitors with potential antifungal activity: A review. Molecules 2019, 24, 1950. [CrossRef]

60. Kovács, R.; Majoros, L. Fungal quorum-sensing molecules: A review of their antifungal effect against Candida biofilms. J. Fungi 2020, 6, 99. [CrossRef]

61. Barriuso, J.; Hogan, D.A.; Keshavarz, T.; Martínez, M.J. Role of quorum sensing and chemical communication in fungal biotechnology and pathogenesis. Fems Microbiol. Rev. 2018, 42, 627-638. [CrossRef]

62. Rodrigues, C.F.; Černáková, L. Farnesol and tyrosol: Secondary metabolites with a crucial quorum-sensing role in Candida biofilm development. Genes 2020, 11, 444. [CrossRef] [PubMed]

63. Padder, S.A.; Prasad, R.; Shah, A.H. Quorum sensing: A less known mode of communication among fungi. Microbiol. Res. 2018, 210, 51-58. [CrossRef] [PubMed]

64. Zawrotniak, M.; Wojtalik, K.; Rapala-Kozik, M. Farnesol, a quorum-sensing molecule of Candida albicans triggers the release of neutrophil extracellular traps. Cells 2019, 8, 1611. [CrossRef]

65. Kean, R.; Delaney, C.; Sherry, L.; Borman, A.; Johnson, E.M.; Richardson, M.D.; Rautemaa-Richardson, R.; Williams, C.; Ramage, G. Transcriptome assembly and profiling of Candida auris reveals novel insights into biofilm-mediated resistance. Msphere 2018, 3, e00334-18. [CrossRef]

66. Rodrigues, C.F.; Rodrigues, M.E.; Silva, S.; Henriques, M. Candida glabrata biofilms: How far have we come? J. Fungi $2017,3,11$. [CrossRef] [PubMed]

67. Shi, C.; Liu, J.; Li, W.; Zhao, Y.; Meng, L.; Xiang, M. Expression of fluconazole resistance-associated genes in biofilm from 23 clinical isolates of Candida albicans. Braz. J. Microbiol. 2019, 50, 157-163. [CrossRef] [PubMed]

68. Chaabane, F.; Graf, A.; Jequier, L.; Coste, A.T. Review on antifungal resistance mechanisms in the emerging pathogen Candida auris. Front. Microbiol. 2019, 10, 2788. [CrossRef] [PubMed]

69. Deng, K.; Jiang, W.; Jiang, Y.; Deng, Q.; Cao, J.; Yang, W.; Zhao, X. ALS3 expression as an indicator for Candida albicans biofilm formation and drug resistance. Front. Microbiol. 2021, 12, 655242. [CrossRef]

70. Chong, P.P.; Chin, V.K.; Wong, W.F.; Madhavan, P.; Yong, V.C.; Looi, C.Y. Transcriptomic and genomic approaches for unravelling Candida albicans biofilm formation and drug resistance-An update. Genes 2018, 9, 540. [CrossRef]

71. Lee, J.-H.; Kim, Y.-G.; Gupta, V.K.; Manoharan, R.K.; Lee, J. Suppression of fluconazole resistant Candida albicans biofilm formation and filamentation by methylindole derivatives. Front. Microbiol. 2018, 9, 2641. [CrossRef] [PubMed]

72. Sasani, E.; Khodavaisy, S.; Rezaie, S.; Salehi, M.; Yadegari, M.H. The relationship between biofilm formation and mortality in patients with Candida tropicalis candidemia. Microb. Pathog. 2021, 155, 104889. [CrossRef] 
73. Vega-Chacón, Y.; de Albuquerque, M.C.; Pavarina, A.C.; Goldman, G.H.; Mima, E.G.d.O. Verapamil inhibits efflux pumps in Candida albicans, exhibits synergism with fluconazole, and increases survival of Galleria mellonella. Virulence 2021, 12, 231-243. [CrossRef]

74. Beauvais, A.; Schmidt, C.; Guadagnini, S.; Roux, P.; Perret, E.; Henry, C.; Paris, S.; Mallet, A.; Prévost, M.C.; Latgé, J.P. An extracellular matrix glues together the aerial-grown hyphae of Aspergillus fumigatus. Cell. Microbiol. 2007, 9, 1588-1600. [CrossRef] [PubMed]

75. Córdova-Alcántara, I.M.; Venegas-Cortés, D.L.; Martínez-Rivera, M.Á.; Pérez, N.O.; Rodriguez-Tovar, A.V. Biofilm characterization of Fusarium solani keratitis isolate: Increased resistance to antifungals and UV light. J. Microbiol. 2019, 57, 485-497. [CrossRef]

76. Nett, J.E.; Sanchez, H.; Cain, M.T.; Andes, D.R. Genetic basis of Candida biofilm resistance due to drug-sequestering matrix glucan. Jinfect. Dis. 2010, 202, 171-175. [CrossRef] [PubMed]

77. Kuhn, D.; George, T.; Chandra, J.; Mukherjee, P.; Ghannoum, M. Antifungal susceptibility of Candida biofilms: Unique efficacy of amphotericin B lipid formulations and echinocandins. Antimicrob. Agents Chemother. 2002, 46, 1773-1780. [CrossRef] [PubMed]

78. Mukherjee, P.K.; Chandra, J.; Kuhn, D.M.; Ghannoum, M.A. Mechanism of fluconazole resistance in Candida albicans biofilms: Phase-specific role of efflux pumps and membrane sterols. Infect. Immun. 2003, 71, 4333-4340. [CrossRef] [PubMed]

79. Wu, X.; Zhang, S.; Xu, X.; Shen, L.; Xu, B.; Qu, W.; Zhuang, W.; Locock, K.; Deighton, M.; Qu, Y. RAFT-derived polymethacrylates as a superior treatment for recurrent vulvovaginal candidiasis by targeting biotic biofilms and persister cells. Front. Microbiol. 2019, 10, 2592. [CrossRef] [PubMed]

80. da Silva, M.A.; Baronetti, J.L.; Páez, P.L.; Paraje, M.G. Oxidative imbalance in Candida tropicalis biofilms and its relation with persister cells. Front. Microbiol. 2021, 11, 598834. [CrossRef] [PubMed]

81. Lewis, K. Persister cells, dormancy and infectious disease. Nat. Rev. Microbiol. 2007, 5, 48-56. [CrossRef]

82. Wu, X.; Zhang, S.; Li, H.; Shen, L.; Dong, C.; Sun, Y.; Chen, H.; Xu, B.; Zhuang, W.; Deighton, M. Biofilm formation of Candida albicans facilitates fungal infiltration and persister cell formation in vaginal candidiasis. Front. Microbiol. 2020, 11, 1117. [CrossRef] [PubMed]

83. Galdiero, E.; de Alteriis, E.; De Natale, A.; D’Alterio, A.; Siciliano, A.; Guida, M.; Lombardi, L.; Falanga, A.; Galdiero, S. Eradication of Candida albicans persister cell biofilm by the membranotropic peptide gH625. Sci. Rep. 2020, 10, 5780. [CrossRef] [PubMed]

84. K Redhu, A.; Shah, A.H.; Prasad, R. MFS transporters of Candida species and their role in clinical drug resistance. Fems Yeast Res. 2016, 16, fow043. [CrossRef] [PubMed]

85. Sun, N.; Li, D.; Fonzi, W.; Li, X.; Zhang, L.; Calderone, R. Multidrug-resistant transporter Mdr1p-mediated uptake of a novel antifungal compound. Antimicrob. Agents Chemother. 2013, 57, 5931-5939. [CrossRef]

86. Van Acker, H.; Van Dijck, P.; Coenye, T. Molecular mechanisms of antimicrobial tolerance and resistance in bacterial and fungal biofilms. Trends Microbiol. 2014, 22, 326-333. [CrossRef]

87. García-Sánchez, S.; Aubert, S.; Iraqui, I.; Janbon, G.; Ghigo, J.-M.; d’Enfert, C. Candida albicans biofilms: A developmental state associated with specific and stable gene expression patterns. Eukaryot. Cell 2004, 3, 536-545. [CrossRef]

88. Dižová, S.; Černáková, L.; Bujdáková, H. The impact of farnesol in combination with fluconazole on Candida albicans biofilm: Regulation of ERG20, ERG9, and ERG11 genes. Folia Microbiol. 2018, 63, 363-371. [CrossRef] [PubMed]

89. Alizadeh, F.; Khodavandi, A.; Esfandyari, S.; Nouripour-Sisakht, S. Analysis of ergosterol and gene expression profiles of sterol $\Delta$ 5, 6-desaturase (ERG3) and lanosterol 14 $\alpha$-demethylase (ERG11) in Candida albicans treated with carvacrol. J. Herbmed Pharmacol. 2018, 7, 79-87. [CrossRef]

90. Fattouh, N.; Hdayed, D.; Geukgeuzian, G.; Tokajian, S.; Khalaf, R.A. Molecular mechanism of fluconazole resistance and pathogenicity attributes of Lebanese Candida albicans hospital isolates. Fungal Genet. Biol. 2021, 153, 103575. [CrossRef]

91. Fernandes, T.; Silva, S.; Henriques, M. Effect of voriconazole on Candida tropicalis biofilms: Relation with ERG genes expression. Mycopathologia 2016, 181, 643-651. [CrossRef]

92. Nailis, H.; Vandenbosch, D.; Deforce, D.; Nelis, H.J.; Coenye, T. Transcriptional response to fluconazole and amphotericin B in Candida albicans biofilms. Res. Microbiol. 2010, 161, 284-292. [CrossRef] [PubMed]

93. Coenye, T.; Nelis, H.J. In vitro and in vivo model systems to study microbial biofilm formation. J. Microbiol. Methods 2010, 83, 89-105. [CrossRef]

94. Pierce, C.G.; Uppuluri, P.; Tristan, A.R.; Wormley, F.L.; Mowat, E.; Ramage, G.; Lopez-Ribot, J.L. A simple and reproducible 96-well plate-based method for the formation of fungal biofilms and its application to antifungal susceptibility testing. Nat. Protoc. 2008, 3, 1494-1500. [CrossRef]

95. Stockert, J.C.; Horobin, R.W.; Colombo, L.L.; Blázquez-Castro, A. Tetrazolium salts and formazan products in cell biology: Viability assessment, fluorescence imaging, and labeling perspectives. Acta Histochem. 2018, 120, 159-167. [CrossRef] [PubMed]

96. Azeredo, J.; Azevedo, N.F.; Briandet, R.; Cerca, N.; Coenye, T.; Costa, A.R.; Desvaux, M.; Di Bonaventura, G.; Hébraud, M.; Jaglic, Z. Critical review on biofilm methods. Crit. Rev. Microbiol. 2017, 43, 313-351. [CrossRef]

97. Kowalski, C.H.; Kerkaert, J.D.; Liu, K.-W.; Bond, M.C.; Hartmann, R.; Nadell, C.D.; Stajich, J.E.; Cramer, R.A. Fungal biofilm morphology impacts hypoxia fitness and disease progression. Nat. Microbiol. 2019, 4, 2430-2441. [CrossRef] [PubMed]

98. Pamp, S.J.; Sternberg, C.; Tolker-Nielsen, T. Insight into the microbial multicellular lifestyle via flow-cell technology and confocal microscopy. Cytom. Part A J. Int. Soc. Anal. Cytol. 2009, 75, 90-103. [CrossRef] [PubMed] 
99. Shao, J.; Lu, K.; Tian, G.; Cui, Y.; Yan, Y.; Wang, T.; Zhang, X.; Wang, C. Lab-scale preparations of Candida albicans and dual Candida albicans-Candida glabrata biofilms on the surface of medical-grade polyvinyl chloride (PVC) perfusion tube using a modified gravity-supported free-flow biofilm incubator (GS-FFBI). J. Microbiol. Methods 2015, 109, 41-48. [CrossRef]

100. Thieme, L.; Hartung, A.; Tramm, K.; Klinger-Strobel, M.; Jandt, K.D.; Makarewicz, O.; Pletz, M.W. MBEC versus MBIC: The lack of differentiation between biofilm reducing and inhibitory effects as a current problem in biofilm methodology. Biol. Proced. Online 2019, 21, 1-5. [CrossRef]

101. Van Dijck, P.; Sjollema, J.; Cammue, B.P.; Lagrou, K.; Berman, J.; d'Enfert, C.; Andes, D.R.; Arendrup, M.C.; Brakhage, A.A.; Calderone, R. Methodologies for in vitro and in vivo evaluation of efficacy of antifungal and antibiofilm agents and surface coatings against fungal biofilms. Microb. Cell 2018, 5, 300. [CrossRef]

102. Pukkila-Worley, R.; Peleg, A.Y.; Tampakakis, E.; Mylonakis, E. Candida albicans hyphal formation and virulence assessed using a Caenorhabditis elegans infection model. Eukaryot. Cell 2009, 8, 1750-1758. [CrossRef] [PubMed]

103. Nett, J.E.; Andes, D.R. Fungal biofilms: In vivo models for discovery of anti-biofilm drugs. Microb. Biofilms 2015, 33-49. [CrossRef]

104. Baria, D.; Shah, U.; Egbuna, C.; Mtewa, A.G. Secondary Metabolites and Toxins of Microbial Origin for the Treatment of Diseases; John Wiley \& Sons, Inc.: Hoboken, NJ, USA, 2020; pp. 225-248.

105. Huang, K.; Zhang, B.; Shen, Z.-Y.; Cai, X.; Liu, Z.-Q.; Zheng, Y.-G. Enhanced amphotericin B production by genetically engineered Streptomyces nodosus. Microbiol. Res. 2021, 242, 126623. [CrossRef] [PubMed]

106. Valente, S.; Cometto, A.; Piombo, E.; Meloni, G.R.; Ballester, A.-R.; González-Candelas, L.; Spadaro, D. Elaborated regulation of griseofulvin biosynthesis in Penicillium griseofulvum and its role on conidiation and virulence. Int. J. Food Microbiol. 2020, 328, 108687. [CrossRef] [PubMed]

107. Wei, T.-Y.; Wu, Y.-J.; Xie, Q.-P.; Tang, J.-W.; Yu, Z.-T.; Yang, S.-B.; Chen, S.-X. CRISPR/Cas9-based genome editing in the filamentous fungus Glarea lozoyensis and its application in manipulating gloF. ACS Synth. Biol. 2020, 9, 1968-1977. [CrossRef]

108. Ebadzadsahrai, G.; Higgins Keppler, E.A.; Soby, S.D.; Bean, H.D. Inhibition of fungal growth and induction of a novel volatilome in response to Chromobacterium vaccinii volatile organic compounds. Front. Microbiol. 2020, 11, 1035. [CrossRef]

109. Butts, A.; Krysan, D.J. Antifungal drug discovery: Something old and something new. Plos Pathog. 2012, 8, e1002870. [CrossRef]

110. Giordani, C.; Simonetti, G.; Natsagdorj, D.; Choijamts, G.; Ghirga, F.; Calcaterra, A.; Quaglio, D.; De Angelis, G.; Toniolo, C.; Pasqua, G. Antifungal activity of Mongolian medicinal plant extracts. Nat. Prod. Res. 2020, 34, 449-455. [CrossRef]

111. Oltu, I.; Cepoi, L.; Rudic, V.; Rudi, L.; Chiriac, T.; Valuta, A.; Codreanu, S. Current Research and New Perspectives in Antifungal Drug Development; Springer Nature: Cham, Switzeralnd, 2019; pp. 71-83.

112. Powers, C.N.; Osier, J.L.; McFeeters, R.L.; Brazell, C.B.; Olsen, E.L.; Moriarity, D.M.; Satyal, P.; Setzer, W.N. Antifungal and cytotoxic activities of sixty commercially available essential oils. Molecules 2018, 23, 1549. [CrossRef]

113. Dewi, I.C.; Falaise, C.; Hellio, C.; Bourgougnon, N.; Mouget, J.-L. Anticancer, Antiviral, Antibacterial, and Antifungal Properties in Microalgae; Academic Press, Elsevier: London, UK, 2018; pp. 235-261.

114. Mickymaray, S.; Alturaiki, W. Antifungal efficacy of marine macroalgae against fungal isolates from bronchial asthmatic cases Molecules 2018, 23, 3032. [CrossRef]

115. Deshmukh, S.K.; Gupta, M.K.; Prakash, V.; Saxena, S. Endophytic fungi: A source of potential antifungal compounds. J. Fungi 2018, 4, 77. [CrossRef]

116. Xu, L.; Meng, W.; Cao, C.; Wang, J.; Shan, W.; Wang, Q. Antibacterial and antifungal compounds from marine fungi. Mar. Drugs 2015, 13, 3479-3513. [CrossRef]

117. Alves, C.T.; Ferreira, I.C.; Barros, L.; Silva, S.; Azeredo, J.; Henriques, M. Antifungal activity of phenolic compounds identified in flowers from North Eastern Portugal against Candida species. Future Microbiol. 2014, 9, 139-146. [CrossRef] [PubMed]

118. Seleem, D.; Pardi, V.; Murata, R.M. Review of flavonoids: A diverse group of natural compounds with anti-Candida albicans activity in vitro. Arch. Oral Biol. 2017, 76, 76-83. [CrossRef]

119. Futuro, D.O.; Ferreira, P.G.; Nicoletti, C.D.; Borba-Santos, L.P.; SILVA, F.C.; Rozental, S.; Ferreira, V.F. The antifungal activity of naphthoquinones: An integrative review. An. Acad. Bras. Cienc. 2018, 90, 1187-1214. [CrossRef] [PubMed]

120. Shang, Z.-C.; Han, C.; Xu, J.-L.; Liu, R.-H.; Yin, Y.; Wang, X.-B.; Yang, M.-H.; Kong, L.-Y. Twelve formyl phloroglucinol meroterpenoids from the leaves of Eucalyptus robusta. Phytochemistry 2019, 163, 111-117. [CrossRef]

121. Aldholmi, M.; Marchand, P.; Ourliac-Garnier, I.; Le Pape, P.; Ganesan, A. A decade of antifungal leads from natural products: 2010-2019. Pharmaceuticals 2019, 12, 182. [CrossRef] [PubMed]

122. Girardot, M.; Imbert, C. Natural sources as innovative solutions against fungal biofilms. Fungal Biofilms Relat. Infect. 2016, 931, 105-125.

123. Nazzaro, F.; Fratianni, F.; Coppola, R.; Feo, V.D. Essential oils and antifungal activity. Pharmaceuticals 2017, 10, 86. [CrossRef]

124. Singla, R.K.; Dubey, A.K. Molecules and metabolites from natural products as inhibitors of biofilm in Candida spp. pathogens. Curr. Top. Med. Chem. 2019, 19, 2567-2578. [CrossRef]

125. Song, X.; Xia, Y.-X.; He, Z.-D.; Zhang, H.-J. A review of natural products with anti-biofilm activity. Curr. Org. Chem. 2018, 22, 789-817. [CrossRef]

126. Stringaro, A.; Colone, M.; Angiolella, L. Antioxidant, antifungal, antibiofilm, and cytotoxic activities of Mentha spp. essential oils. Medicines 2018, 5, 112. [CrossRef] 
127. Peixoto, L.R.; Rosalen, P.L.; Ferreira, G.L.S.; Freires, I.A.; de Carvalho, F.G.; Castellano, L.R.; de Castro, R.D. Antifungal activity, mode of action and anti-biofilm effects of Laurus nobilis Linnaeus essential oil against Candida spp. Arch. Oral Biol. 2017, 73, 179-185. [CrossRef] [PubMed]

128. Manoharan, R.K.; Lee, J.-H.; Kim, Y.-G.; Kim, S.-I.; Lee, J. Inhibitory effects of the essential oils $\alpha$-longipinene and linalool on biofilm formation and hyphal growth of Candida albicans. Biofouling 2017, 33, 143-155. [CrossRef] [PubMed]

129. Serra, E.; Hidalgo-Bastida, L.A.; Verran, J.; Williams, D.; Malic, S. Antifungal activity of commercial essential oils and biocides against Candida albicans. Pathogens 2018, 7, 15. [CrossRef] [PubMed]

130. Banu, S.F.; Rubini, D.; Shanmugavelan, P.; Murugan, R.; Gowrishankar, S.; Pandian, S.K.; Nithyanand, P. Effects of patchouli and cinnamon essential oils on biofilm and hyphae formation by Candida species. J. Mycol. Med. 2018, 28, 332-339. [CrossRef] [PubMed]

131. Bassyouni, R.H.; Wali, I.E.; Kamel, Z.; Kassim, M.F. Fennel oil: A promising antifungal agent against biofilm forming fluconazole resistant Candida albicans causing vulvovaginal candidiasis. J. Herb. Med. 2019, 15, 100227. [CrossRef]

132. Sahal, G.; Woerdenbag, H.J.; Hinrichs, W.L.; Visser, A.; Tepper, P.G.; Quax, W.J.; van der Mei, H.C.; Bilkay, I.S. Antifungal and biofilm inhibitory effect of Cymbopogon citratus (lemongrass) essential oil on biofilm forming by Candida tropicalis isolates; an in vitro study. J. Ethnopharmacol. 2020, 246, 112188. [CrossRef]

133. Choonharuangdej, S.; Srithavaj, T.; Thummawanit, S. Fungicidal and inhibitory efficacy of cinnamon and lemongrass essential oils on Candida albicans biofilm established on acrylic resin: An in vitro study. J. Prosthet. Dent. 2021, 125, 707-e1. [CrossRef]

134. Galletti, J.; Tobaldini-Valerio, F.K.; Silva, S.; Kioshima, É.S.; Trierveiler-Pereira, L.; Bruschi, M.; Negri, M.; Estivalet Svidzinski, T.I. Antibiofilm activity of propolis extract on Fusarium species from onychomycosis. Future Microbiol. 2017, 12, 1311-1321. [CrossRef]

135. Lainhart, W. Fusarium spp., a genus of common plant pathogens that can cause devastating, opportunistic human disease. Clin. Microbiol. Newsl. 2018, 40,1-5. [CrossRef]

136. Martorano-Fernandes, L.; Cavalcanti, Y.W.; de Almeida, L.d.F.D. Inhibitory effect of Brazilian red propolis on Candida biofilms developed on titanium surfaces. BMC Complement. Med. Ther. 2020, 20, 1-9. [CrossRef]

137. Sardi, J.d.C.O.; Freires, I.A.; Lazarini, J.G.; Infante, J.; de Alencar, S.M.; Rosalen, P.L. Unexplored endemic fruit species from Brazil: Antibiofilm properties, insights into mode of action, and systemic toxicity of four Eugenia spp. Microb. Pathog. 2017, 105, $280-287$. [CrossRef]

138. Alizadeh, F.; Khodavandi, A.; Faraji, F.S. Malva sylvestris inhibits Candida albicans biofilm formation. J. Herbmed Pharmacol. 2017, 6, 62-68.

139. Silva, D.R.; Rosalen, P.L.; Freires, I.A.; Sardi, J.d.C.O.; Lima, R.F.; Lazarini, J.G.; Costa, T.K.V.L.d.; Pereira, J.V.; Godoy, G.P.; Costa, E.M.M.d.B. Anadenanthera colubrina vell Brenan: Anti-Candida and antibiofilm activities, toxicity and therapeutical action. Braz. Oral Res. 2019, 33, e023. [CrossRef]

140. Ourabah, A.; Atmani-Kilani, D.; Debbache-Benaida, N.; Kolesova, O.; Azib, L.; Yous, F.; Benloukil, M.; Botta, B.; Atmani, D.; Simonetti, G. Anti-Candida albicans biofilm activity of extracts from two selected indigenous Algerian plants: Clematis flammula and Fraxinus angustifolia. J. Herb. Med. 2020, 20, 100319. [CrossRef]

141. Dwivedi, M.; Muralidhar, S.; Saluja, D. Hibiscus sabdariffa extract inhibits adhesion, biofilm initiation and formation in Candida albicans. Indian J. Microbiol. 2020, 60, 96-106. [CrossRef] [PubMed]

142. Rahmasari, R.; Chairunissa, A.H.; Irianti, M.I.; Forestrania, R.C.; Arifianti, A.E.; Suryadi, H.; Makau, J.N.; Jantan, I.; Elya, B. Inhibitory and anti-biofilm effects of Orthoshipon aristatus against Candida albicans. Pharm. Sci. Res. 2020, 7, 2. [CrossRef]

143. Millot, M.; Girardot, M.; Dutreix, L.; Mambu, L.; Imbert, C. Antifungal and anti-biofilm activities of acetone lichen extracts against Candida albicans. Molecules 2017, 22, 651. [CrossRef] [PubMed]

144. Cepas, V.; López, Y.; Gabasa, Y.; Martins, C.B.; Ferreira, J.D.; Correia, M.J.; Santos, L.; Oliveira, F.; Ramos, V.; Reis, M. Inhibition of bacterial and fungal biofilm formation by 675 extracts from microalgae and cyanobacteria. Antibiotics 2019, 8, 77. [CrossRef]

145. Liu, R.-H.; Shang, Z.-C.; Li, T.-X.; Yang, M.-H.; Kong, L.-Y. In vitro antibiofilm activity of eucarobustol E against Candida albicans. Antimicrob. Agents Chemother. 2017, 61, e02707-e02716. [CrossRef]

146. Shi, G.; Shao, J.; Wang, T.; Wu, D.; Wang, C. Mechanism of berberine-mediated fluconazole-susceptibility enhancement in clinical fluconazole-resistant Candida tropicalis isolates. Biomed. Pharmacother. 2017, 93, 709-712. [CrossRef] [PubMed]

147. Behbehani, J.; Shreaz, S.; Irshad, M.; Karched, M. The natural compound magnolol affects growth, biofilm formation, and ultrastructure of oral Candida isolates. Microb. Pathog. 2017, 113, 209-217. [CrossRef] [PubMed]

148. Kumari, P.; Mishra, R.; Arora, N.; Chatrath, A.; Gangwar, R.; Roy, P.; Prasad, R. Antifungal and anti-biofilm activity of essential oil active components against Cryptococcus neoformans and Cryptococcus laurentii. Front. Microbiol. 2017, 8, 2161. [CrossRef] [PubMed]

149. Qu, J.; Zhang, X.; Lu, Y.; Liu, X.; Lv, X. Clinical analysis in immunocompetent and immunocompromised patients with pulmonary cryptococcosis in western China. Sci. Rep. 2020, 10, 1-11. [CrossRef] [PubMed]

150. Kumari, P.; Arora, N.; Chatrath, A.; Gangwar, R.; Pruthi, V.; Poluri, K.M.; Prasad, R. Delineating the biofilm inhibition mechanisms of phenolic and aldehydic terpenes against Cryptococcus neoformans. ACS Omega 2019, 4, 17634-17648. [CrossRef] [PubMed]

151. Li, S.; Shi, H.; Chang, W.; Li, Y.; Zhang, M.; Qiao, Y.; Lou, H. Eudesmane sesquiterpenes from Chinese liverwort are substrates of Cdrs and display antifungal activity by targeting Erg6 and Erg11 of Candida albicans. Bioorg. Med. Chem. 2017, 25, 5764-5771. [CrossRef] [PubMed]

152. Alalwan, H.; Rajendran, R.; Lappin, D.F.; Combet, E.; Shahzad, M.; Robertson, D.; Nile, C.J.; Williams, C.; Ramage, G. The antiadhesive effect of curcumin on Candida albicans biofilms on denture materials. Front. Microbiol. 2017, 8, 659. [CrossRef] 
153. Lee, J.-H.; Kim, Y.-G.; Choi, P.; Ham, J.; Park, J.G.; Lee, J. Antibiofilm and antivirulence activities of 6-gingerol and 6-shogaol against Candida albicans due to hyphal inhibition. Front. Cell. Infect. Microbiol. 2018, 8, 299. [CrossRef]

154. Yan, Y.; Tan, F.; Miao, H.; Wang, H.; Cao, Y. Effect of shikonin against Candida albicans biofilms. Front. Microbiol. 2019, 10, 1085. [CrossRef]

155. Saibabu, V.; Fatima, Z.; Ahmad, K.; Khan, L.; Hameed, S. Efficiency of vanillin in impeding metabolic adaptability and virulence of Candida albicans by inhibiting glyoxylate cycle, morphogenesis, and biofilm formation. Curr. Med. Mycol. 2020, 6, 1-8.

156. Kischkel, B.; Souza, G.K.; Chiavelli, L.U.R.; Pomini, A.M.; Svidzinski, T.I.E.; Negri, M. The ability of farnesol to prevent adhesion and disrupt Fusarium keratoplasticum biofilm. Appl. Microbiol. Biotechnol. 2020, 104, 377-389. [CrossRef] [PubMed]

157. Wang, X.; Jin, X.-Y.; Zhou, J.-C.; Zhu, R.-X.; Qiao, Y.-N.; Zhang, J.-Z.; Li, Y.; Zhang, C.-Y.; Chen, W.; Chang, W.-Q. Terpenoids from the Chinese liverwort Heteroscyphus coalitus and their anti-virulence activity against Candida albicans. Phytochemistry 2020, 174, 112324. [CrossRef] [PubMed]

158. Das, S.; Czuni, L.; Báló, V.; Papp, G.; Gazdag, Z.; Papp, N.; Kőszegi, T. Cytotoxic action of artemisinin and scopoletin on planktonic forms and on biofilms of Candida species. Molecules 2020, 25, 476. [CrossRef] [PubMed]

159. Lemos, A.S.; Florêncio, J.R.; Pinto, N.C.; Campos, L.M.; Silva, T.P.; Grazul, R.M.; Pinto, P.F.; Tavares, G.D.; Scio, E.; Apolônio, A.C.M. Antifungal activity of the natural coumarin scopoletin against planktonic cells and biofilms from a multidrug-resistant Candida tropicalis strain. Front. Microbiol. 2020, 11, 1525. [CrossRef] [PubMed]

160. Kipanga, P.N.; Liu, M.; Panda, S.K.; Mai, A.H.; Veryser, C.; Van Puyvelde, L.; De Borggraeve, W.M.; Van Dijck, P.; Matasyoh, J.; Luyten, W. Biofilm inhibiting properties of compounds from the leaves of Warburgia ugandensis Sprague subsp ugandensis against Candida and staphylococcal biofilms. J. Ethnopharmacol. 2020, 248, 112352. [CrossRef]

161. Liu, Y.; Ren, H.; Wang, D.; Zhang, M.; Sun, S.; Zhao, Y. The synergistic antifungal effects of gypenosides combined with fluconazole against resistant Candida albicans via inhibiting the drug efflux and biofilm formation. Biomed. Pharmacother. 2020, 130, 110580. [CrossRef]

162. Zhao, M.; Zhang, F.; Zarnowski, R.; Barns, K.; Jones, R.; Fossen, J.; Sanchez, H.; Rajski, S.R.; Audhya, A.; Bugni, T.S. Turbinmicin inhibits Candida biofilm growth by disrupting fungal vesicle-mediated trafficking. J. Clin. Investig. 2021, 131, e145123. [CrossRef]

163. Zarnowski, R.; Sanchez, H.; Covelli, A.S.; Dominguez, E.; Jaromin, A.; Bernhardt, J.; Mitchell, K.F.; Heiss, C.; Azadi, P.; Mitchell, A. Candida albicans biofilm-induced vesicles confer drug resistance through matrix biogenesis. Plos Biol. 2018, 16, e2006872. [CrossRef]

164. Zainal, M.; Zain, N.M.; Amin, I.M.; Ahmad, V.N. The antimicrobial and antibiofilm properties of allicin against Candida albicans and Staphylococcus aureus-A therapeutic potential for denture stomatitis. Saudi Dent. J. 2021, 33, 105-111. [CrossRef]

165. Feldman, M.; Sionov, R.V.; Mechoulam, R.; Steinberg, D. Anti-biofilm activity of cannabidiol against Candida albicans. Microorganisms 2021, 9, 441. [CrossRef]

166. Ivanov, M.; Kannan, A.; Stojković, D.S.; Glamočlija, J.; Calhelha, R.C.; Ferreira, I.C.; Sanglard, D.; Soković, M. Camphor and eucalyptol-aticandidal spectrum, antivirulence effect, efflux pumps interference and cytotoxicity. Int. J. Mol. Sci. 2021, 22, 483. [CrossRef]

167. Kovács, R.; Nagy, F.; Tóth, Z.; Forgács, L.; Tóth, L.; Váradi, G.; Tóth, G.K.; Vadászi, K.; Borman, A.M.; Majoros, L. The Neosartorya fischeri antifungal protein 2 (NFAP2): A new potential weapon against multidrug-resistant Candida auris biofilms. Int. J. Mol. Sci. 2021, 22, 771. [CrossRef]

168. Lin, C.-H.; Kabrawala, S.; Fox, E.P.; Nobile, C.J.; Johnson, A.D.; Bennett, R.J. Genetic control of conventional and pheromonestimulated biofilm formation in Candida albicans. PLoS Pathog. 2013, 9, e1003305. [CrossRef]

169. Quatrin, P.M.; Verdi, C.M.; de Souza, M.E.; de Godoi, S.N.; Klein, B.; Gundel, A.; Wagner, R.; de Almeida Vaucher, R.; Ourique, A.F.; Santos, R.C.V. Antimicrobial and antibiofilm activities of nanoemulsions containing Eucalyptus globulus oil against Pseudomonas aeruginosa and Candida spp. Microb. Pathog. 2017, 112, 230-242. [CrossRef]

170. Sudjana, A.N.; Carson, C.F.; Carson, K.C.; Riley, T.V.; Hammer, K.A. Candida albicans adhesion to human epithelial cells and polystyrene and formation of biofilm is reduced by sub-inhibitory Melaleuca alternifolia (tea tree) essential oil. Med. Mycol. 2012, 50, 863-870. [CrossRef]

171. Souza, M.; Lopes, L.; Bonez, P.; Gündel, A.; Martinez, D.; Sagrillo, M.; Giongo, J.; Vaucher, R.; Raffin, R.; Boligon, A.; et al. Melaleuca alternifolia nanoparticles against Candida species biofilms. Microb. Pathog. 2017, 104, 125-132. [CrossRef] [PubMed]

172. Ma, S.; Moser, D.; Han, F.; Leonhard, M.; Schneider-Stickler, B.; Tan, Y. Preparation and antibiofilm studies of curcumin loaded chitosan nanoparticles against polymicrobial biofilms of Candida albicans and Staphylococcus aureus. Carbohydr. Polym. 2020, 241, 116254. [CrossRef]

173. Gumus, B.; Acar, T.; Atabey, T.; Derman, S.; Sahin, F.; Arasoglu, T. The battle against biofilm infections: Juglone loaded nanoparticles as an anticandidal agent. J. Biotechnol. 2020, 316, 17-26. [CrossRef] [PubMed]

174. Rajasekar, V.; Darne, P.; Prabhune, A.; Kao, R.Y.; Solomon, A.P.; Ramage, G.; Samaranayake, L.; Neelakantan, P. A curcuminsophorolipid nanocomplex inhibits Candida albicans filamentation and biofilm development. Colloids Surf. B. Biointerfaces 2021, 200, 111617. [CrossRef] [PubMed]

175. Rodrigues, C.F.; Silva, S.; Henriques, M. Candida glabrata: A review of its features and resistance. Eur. J. Clin. Microbiol. Infect. Dis. 2014, 33, 673-688. [CrossRef]

176. Sabino, R.; Veríssimo, C.; Pereira, Á.A.; Antunes, F. Candida auris, an agent of hospital-associated outbreaks: Which challenging issues do we need to have in mind? Microorganisms 2020, 8, 181. [CrossRef] 
177. Ademe, M.; Girma, F. Candida auris: From multidrug resistance to pan-resistant strains. Infect. Drug Resist. 2020, $13,1287$.

178. Zhang, Y.; Yang, H.; Turra, D.; Zhou, S.; Ayhan, D.H.; DeIulio, G.A.; Guo, L.; Broz, K.; Wiederhold, N.; Coleman, J.J.; et al. The genome of opportunistic fungal pathogen Fusarium oxysporum carries a unique set of lineage-specific chromosomes. Commun. Biol. 2020, 3, 50. [CrossRef]

179. Oliveira dos Santos, C.; Kolwijck, E.; van Rooij, J.; Stoutenbeek, R.; Visser, N.; Cheng, Y.Y.; Santana, N.T.; Verweij, P.E.; Eggink, C.A. Epidemiology and clinical management of Fusarium keratitis in the Netherlands, 2005-2016. Front. Cell. Infect. Microbiol. 2020, 10, 133. [CrossRef] [PubMed]

180. Mukherjee, P.K.; Chandra, J.; Yu, C.; Sun, Y.; Pearlman, E.; Ghannoum, M.A. Characterization of Fusarium keratitis outbreak isolates: Contribution of biofilms to antimicrobial resistance and pathogenesis. Invest. Ophthalmol. Vis. Sci. 2012, 53, 4450-4457. [CrossRef] [PubMed]

181. Hino, Y.; Muraosa, Y.; Oguchi, M.; Yahiro, M.; Yarita, K.; Watanabe, A.; Sakaida, E.; Yokote, K.; Kamei, K. Drain outlets in patient rooms as sources for invasive fusariosis: An analysis of patients with haematological disorders. J. Hosp. Infect. 2020, 105, 518-526. [CrossRef] [PubMed]

182. Qian, W.; Yang, M.; Li, X.; Sun, Z.; Li, Y.; Wang, X.; Wang, T. Anti-microbial and anti-biofilm activities of combined chelerythrinesanguinarine and mode of action against Candida albicans and Cryptococcus neoformans in vitro. Colloids Surf. B. Biointerfaces 2020, 191, 111003. [CrossRef]

183. Harding, M.W.; Marques, L.L.; Howard, R.J.; Olson, M.E. Can filamentous fungi form biofilms? Trends Microbiol. 2009, 17, 475-480. [CrossRef] [PubMed]

184. Costa-Orlandi, C.; Sardi, J.; Santos, C.; Fusco-Almeida, A.; Mendes-Giannini, M.J.S. In vitro characterization of Trichophyton rubrum and T. mentagrophytes biofilms. Biofouling 2014, 30, 719-727. [CrossRef] [PubMed]

185. Lu, L.; Hu, W.; Tian, Z.; Yuan, D.; Yi, G.; Zhou, Y.; Cheng, Q.; Zhu, J.; Li, M. Developing natural products as potential anti-biofilm agents. Chin. Med. 2019, 14,1-17. [CrossRef] [PubMed] 